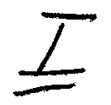

\author{
ARGONNE NATIONAL LABORATORY \\ P. O. Box 299 \\ Lemont, Illinois
}

\title{
RADIATION SAFETY GUIDE
}

J. R. Novak, Editor

\section{Industrial Hygiene \& Safety Division}

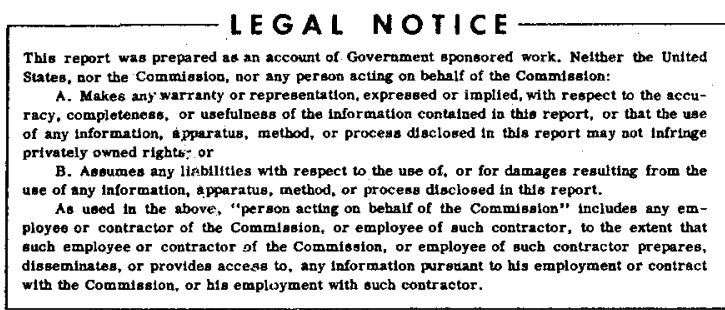

$$
\text { June, } 1956
$$

Operated by The University of Chicago under

Contract W-31-109-eng- 38 


\section{DISCLAIMER}

This report was prepared as an account of work sponsored by an agency of the United States Government. Neither the United States Government nor any agency Thereof, nor any of their employees, makes any warranty, express or implied, or assumes any legal liability or responsibility for the accuracy, completeness, or usefulness of any information, apparatus, product, or process disclosed, or represents that its use would not infringe privately owned rights. Reference herein to any specific commercial product, process, or service by trade name, trademark, manufacturer, or otherwise does not necessarily constitute or imply its endorsement, recommendation, or favoring by the United States Government or any agency thereof. The views and opinions of authors expressed herein do not necessarily state or reflect those of the United States Government or any agency thereof. 


\section{DISCLAIMER}

Portions of this document may be illegible in electronic image products. Images are produced from the best available original document. 
This Guide began as the cooperative effort of a six-man committee. Paul R. Fields of the Chemistry Division, Victor $H$. Munnecke of the Chemical Engineering Division, and Sol Wexler of the Physics Division represented the prime users of the Guide, the scientific staff of Argonne National Laboratory. Alvin Glassner of the Technical Information Division was responsible for compiling the information. John T. Bobbitt, Assistant Laboratory Director, was concerned primarily with the viewpoint of Laboratory management. John F. Ege, Jr., of the Industrial Hygiene and Safety Division, represented the Radiation Safety personnel.

In December 1954, the preliminary draft of the Guide was distributed for critical review. A. M. Brues, G. H. Dickerson, J. G. Feldes, Jr., A. J. Finkel, M. E. Gahlon, J.R. Gilbreath, E. L. Hall, E. A. Hathaway, A. F. Miller, D. P. O'Neil, A. W.R. Oswald, J.H. Pingel, J. E. Rose, and $H$. V. Ross made suggestions which were incorporated in the draft copy of the Guide issued in March 1955. Additional suggestions made by M. Grotenhuis, E. L. Hall, E. L. Kelso, V. H. Munnecke, D. P. O' Neil, and C. H. Youngquist have been included in the present Guide.

J. R. Novak Editor 
I. INTRODUCTION $\ldots \ldots \ldots \ldots \ldots \ldots \ldots \ldots \ldots \ldots$

II. EMERGENCY PROCEDURES ................. 3

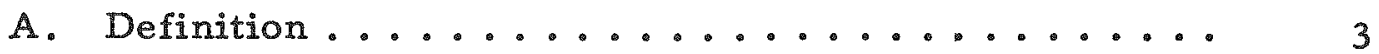

B. Emergency Procedure .................. 3

C. Cleaning the Area Contaminated by the Spill ..... 4

III. GENERAL LABORATORY REGULATIONS AND PROCEDURES FOR WORKING WITH RADIO-

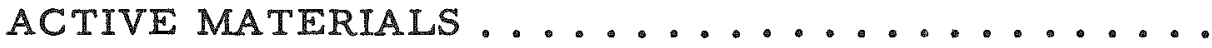

A. Working at Night and on Holidays .......... 5

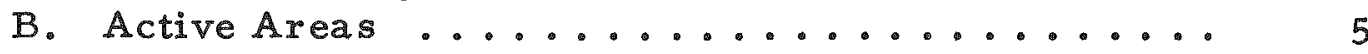

C. Procedures Relating to Working Around Piles

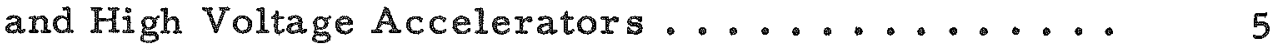

D. Eating and Smoking Regulations ............. 6

E. Wearing of Personnel Monitoring Devices ...... 6

F. Regulations Applying to Maintenance and

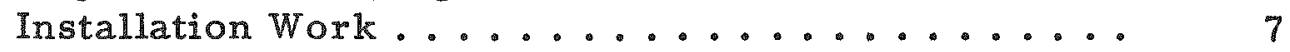

G. Use of Radiation Safety Service ............ 7

H. Regulations Applying to Shipment .......... 7

IV. RADIOACTIVITY AND HAZARDS ............. 9

A. Nature of Radiations ................. 9

B. Biological Consequences Resulting from

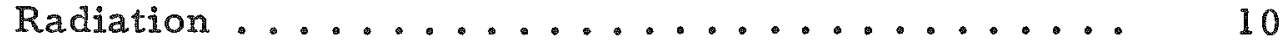

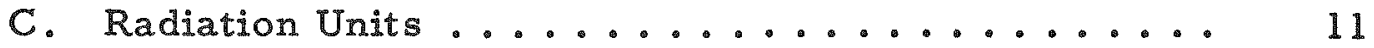

D. Permissible Exposure Levels ............. 12

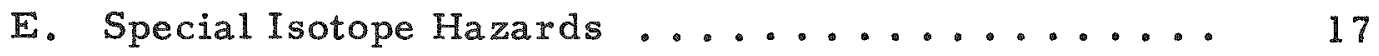

F. Preventing Contamination .............. 18

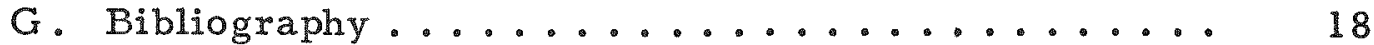

V. PRECAUTIONS IN HANDLING RADIOACTIVE

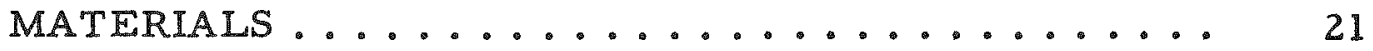

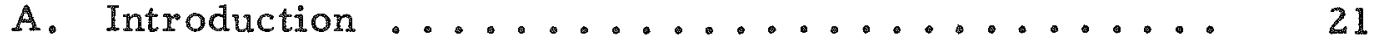

1. Protection from External Radiation......... 21

2. Protection from Internal Radiation ........ 21

3. Precautions with Regard to Beams from Reactors and Accelerators ........... 
TABLE OF CONTENTS

Page

4. General Housekeeping Methods ......... 22

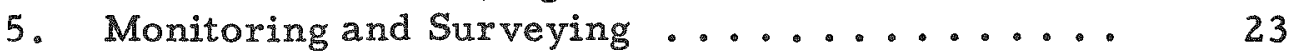

6. Preventing Spread of Contamination ....... 23

7. Reporting Exposure ............... 24

8. Special Facilities for Operations with Hazardous Levels of Activity ............ 24

B. Precautions in Handling Alpha-Active Materials . . 25

1. The Use of Hoods and Dry Boxes ......... 26

2. Use of Respiratory Equipment and Protective

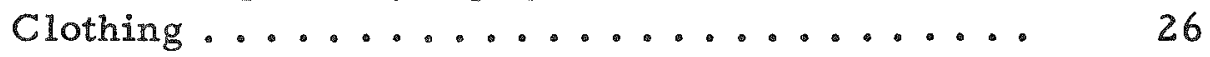

3. Care to be Taken in Pipetting, Centrifuging,

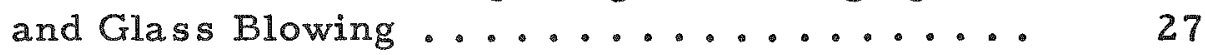

4. Disposal of Alpha-Active Wastes ......... 28

5. Disposal of Contaminated Equipment ....... 28

6. Neutron Hazards from Alpha Emitters...... 29

C. Precautions in Handling Beta- and Gamma-Active Materials...................... 29

1. Protection from External Radiation........ 29

2. Protection from Internal Radiation ........ 34

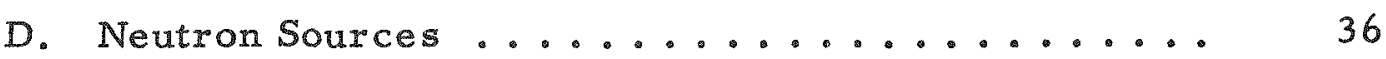

1. Protection from External Sources......... 36

2. Protection from Internal Sources ......... 37

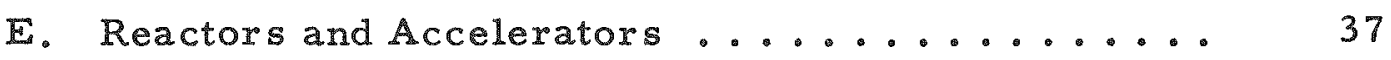

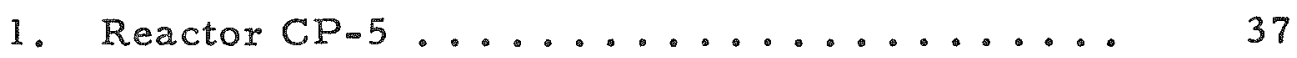

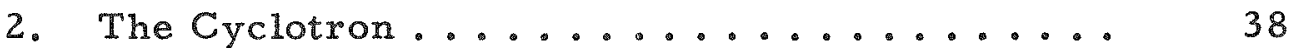

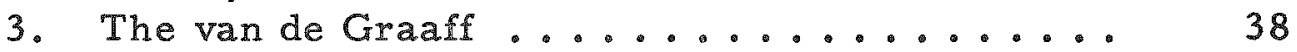

4. Reactor CP-4 (Idaho Falls) ............ 39

VI. STORAGE AND DISPOSAL OF ACTIVE SAMPLES . ... 41

A. Dry Active Wastes ................... 41

B. Liquid Wastes ...................... 41

C. Ventilated Storage for Gaseous Emitters ....... 42

D. Use of Secondary Containers in Storage ........ 42

E. Contaminated Equipment ............... 44

VII. TRANSPORTING ACTIVE MATERIALS ON AND OFF

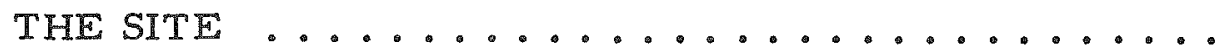


VIII. IRRADIATING SAMPLES ................... 47

A. Reactor CP-5 .................... 47

B. The Cyclotron ..................... 47

C. The van de Graaff .................. 47

D. X-Ray and Gamma-Ray Facilities ........... 47

E. Reactor CP-4 (Idaho Falls) .............. 48

IX. DECONTAMINATION PROCEDURES ........... 49

A. Personal Decontamination .............. 49

1. Procedure for Washing Contaminated Skin and

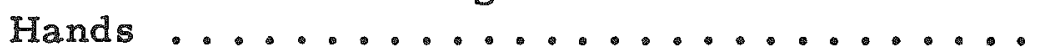

2. Titanium Dioxide to Remove Fission Products .....................

3. Potassium Permanganate to Remove Plutonium . . . . . . . . . . . . . . . .

B. Decontaminating Laboratory Equipment and Apparatus...................... 51

C. Decontaminating Laboratory Work Areas ....... 52

X. BIBLIOGRAPHY.................... 55

\section{APPENDICES}

I. Technique for Putting on and Removing Rubber Gloves .......................

II. General Safety Precautions and Rules ........ 61

III. Surveying and Monitoring Instruments ....... 65

IV. Personnel Monitoring Devices ............ 67 
Figure 1 Half Thicknesses for Various Materials as a Function of Photon Energy .............. 31

Table I Provisional Levels of Permissible Concentration of Radioactive Contaminants ............. 13

Table II Maximum Permissible Exposure and Operating Levels for Some Alpha Emitters ............ 14

Table III Maximum Permissible Exposure and Operating Levels for Some Beta and Gamma Emitters ....... 15

Table IV Maximum Permissible Exposures for External

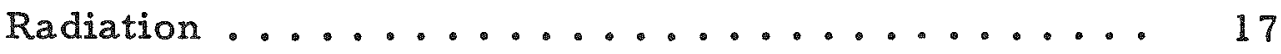

Table V Maximum Permissible Neutron Flux Densities .... 17

Table VI Half Thicknesses in Inches for Various Materials at Varying Gamma Energies ............. 
$=1$

RADIATION SAFETY GUIDE

J. R. Novak, Editor

I. INTRODUCTION

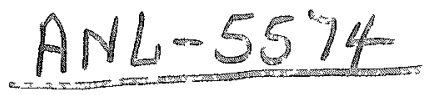

Work with radioactive substances may involve some danger, and safety precautions must be taken before the work is started. This Guide includes suggested precautions to provide adequate protection, as well as some general information concerning possible radiation hazards and the effects of radiation on the body. It also contains procedural information sis. which will help you cope with radiation safety problems as they occur

Radiations need not be feared when properly understood. As in driving a car, danger can usually be avoided if caution and common sense are used. All the basic rules and devices for providing radiation safety are founded on these principles and on the experience gained by scientific investigators. Like a set of traffic rules, they are not sacred, but they are to be followed until wiser regulations are forthcoming.

You are primarily responsible for your own safety. While aid to the solution of your radiation safety problem may be obtained from other personnel, the actual work will be done by you, and you will be the one who will suffer from accidents or malpractice. Skill in radiation protection is as necessary as skill in chemical or physical manipulations. Take advantage of the Laboratory's facilities for your own protection. Short cuts, while they may save time, are often dangerous.

It is obviously impossible to set down rules for the handling of radioactive materials which will apply in every case. It is intended that recommendations of only a general nature be considered. Read this manual and be guided accordingly. If your particular problems are not covered. seek help. Get the advice of your group or section leader. If he cannot help you directly, he will know whom to contact. It is your responsibility as an employee of Argonne National Laboratory to take action whenever you feel uneasy about the environment in which you work. Use existing channels to present your problems to a person who is qualified to help you. You are also at liberty to consult with members of the Health Division and Industrial Hygiene and Safety at any time on these matters. This may be done with or without the prior approval of your supervisor.

As you read this Guide you will notice that parts of it are repeated in various sections. For example, some of the instructions for handling alpha emitters apply equally well to handling beta and gamma emitters. 


$$
2
$$

Those instructions appear in the section on alpha emitters and also in the section where beta and gamma emitters are discussed. Insofar as it is feasible, each section is a complete unit. In general, each section contains a summary at the beginning, followed by a detailed account. It is hoped that this procedure will make it unnecessary for you to hunt through the Guide for pertinent information when you need it. 
II. EMERGENCY PROCEDURES

A. Definition

It is difficult to give an exact definition of an emergency, but the Laboratory would rather have employees err on the side of reporting too many incidents than to have a really serious emergency develop because someone delayed too long in deciding whether or not a situation might be an emergency. If immediate action is needed to prevent serious injury or extensive damage, or if you are unable to get help with one routine telephone call, the situation is an emergency - DIAL 13.

Every employee must feel a personal responsibility to report an emergency. Go to the nearest phone and DIAL 13.

\section{B. Emergency Procedure}

The above information applies to all types of emergencies which may occur at the Laboratory. If you spill radioactive material, act as follows:

1. Warn other occupants of the room: hold your breath; leave the room. Remember that your primary responsibility is the safety of yourself and others. Possible loss of materials is entirely secondary. If you have time, while you hold your breath, you may do a few things to prevent the spread of contamination: right containers, drop absorbent pads on liquids. If you hold your breath you will not inhale radioactive particles which may be in the air.

2. Close the door and ask someone to prevent entry until a proper hazard sign is posted. The room may be entered only with the knowledge of a Radiation Safety representative.

3. Wash and flush any radioactive material from your skin. Use the emergency shower if necessary.

4. While you are still washing, ask someone to DIAL 13 and give the details and location of the accident; the emergency operator will notify Radiation Safety.

5. Remove contaminated clothing and place in an active waste container. 
4

6. Check your body for cuts and abrasions. If there are any, whether or not they were caused by the accident, notify the Health Division.

7. Be certain that your supervisor is notified of the incident.

8. Alert personnel in adjoining areas.

9. If no immediate medical attention is needed, wait for the Radiation Safety representative.

C. Cleaning the Area Contaminated by the Spill

All cleaning operations are to be done with the approval of the Radiation Safety Section. 
III. GENERAL LABORATORY REGULATIONS AND PROCEDURES FOR WORKING WITH RADIOACTIVE MATERIALS

A. Working at Night and on Holidays

Radiation Safety must be notified if, at any time other than normal working hours, you intend to work with radioactive materials whose activity is more than $10^{6}$ disintegrations per minute. You must also secure the approval of the Director of your Division if you plan to work alone.

\section{B. Active Areas}

An active area is an area in which radioactive materials are located in such amounts that they constitute a potential personnel hazard or increase the possibility for spread of contamination. Occupants of active areas are responsible for having such areas clearly defined and marked.

Certain regions of the Laboratory have been specifically delineated as areas where radiation hazards normally exist. The se locations have been distinctly designated and marked as such by the authority of the responsible Division Director.

Every individual entering an active area is required to wear personnel monitoring devices, which are found at the entrance to the area. In some areas, toe rubbers, safety glasses, and other types of protective equipment must be worn. Read the instructions which are posted at the entrances to the area and be guided accordingly.

\section{Procedures Relating to Working around Piles and High Voltage Accelerators}

Building 330 , in which the reactor CP-5 is located, is, except for the offices, an active area. It is mandatory that per sonnel monitoring devices be worn. The Radiation Safety Section provides special devices for measuring exposure to neutrons as well as the usual type of detection equipment.

Building 211 , which houses the cyclotron and a small van de Graaff accelerator, is an active area. The building is locked at all times, admission being only by permission of the cyclotron operators. Personnel monitoring equipment for visitors is provided on obtaining entrance to the building. 
Wing G of Building 203, where the large van de Graaff is located, has not been designated as an active area. Access to the experimental portion is forbidden when the machine is in operation. Permission to enter at other times should be obtained from the operators. You must obtain your own personnel monitoring devices in advance from Radiation Safety. Permanent fast neutron monitoring equipment is installed in the area.

The entire Idaho Division Site is an active area and it is mandatory that personnel monitoring devices be worn. The badges at this site contain special films for monitoring beta, gamma, and neutron exposures.

Whenever you are responsible for equipment that emits hazardous beams of radiation, check to be certain that the area is posted and roped-off, or otherwise guarded, to prevent exposure of persons unaware of the dangers involved.

D. Eating and Smoking Regulations

Eating, storing, or preparing food in areas where radioactive materials are handled is prohibited. Protective clothing or devices used in connection with radioactive work shall not be taken into any area where food is stored, prepared, dispensed, or eaten.

Do not smoke in an active area unless specific permission is granted by the supervisor in charge of the area.

E. Wearing of Personnel Monitoring Devices

The Laboratory provides film badges and self-reading dosimeters to all individuals who are required to work in the vicinity of radioactive materials. These must be worn whenever there exists a possibility of exposure to radiation: they are considered as part of normal laboratory equipment. All such devices are to be picked up each morning at the entrance to the active area and returned to the appropriate depository upon leaving the working area.

Dosimeters and film badges must not be tampered with in any way. If you have a discharged dosimeter or one that is suspected of not being in proper working condition, report it immediately to Radiation Safety. Other available types of personnel monitoring devices are described in Appendix IV. 


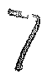

F. Regulations Applying to Maintenance and Installation Work

If your work requires alterations, minor installations, or new construction, initiate the Service Request Form, ANL-36. Routine checks, such as those for filters or hoods, do not require this form. Nevertheless, before such routines are established, the approval of the person in charge of the area and Radiation Safety must be obtained.

Before installation personnel start work, the Work Entry Clearance Form, ANL-18, must be completed by the Plant Operations Supervisor for the area or building. If Radiation Safety approval is required it must be obtained at that time. If hazards do exist the requestor must be present to warn and protect the repair men against any danger. In any case, the requestor is responsible for the safety of the men against chemical and other potential hazards, as well as those due to radiation.

\section{G. Use of Radiation Safety Service}

Consult Radiation Safety whenever you are in doubt about the procedure for handling radioactive materials. Members of this group are available to help solve radiation hazard problems.

Radiation Safety provides monitors for operations which involve radiation. If special personnel monitoring devices are needed, this group will provide them.

\section{H. Regulations Applying to Shipment}

All shipments of radioactive or fissionable materials, with the exception of radioactive wastes and/or contaminated materials, are made through the facilities of the Special Materials Department. No transfer of such materials, whether on- or off-site, is to be made without the authorization of this Department. Radioactive wastes and/or contaminated materials are handled by the Reclamation Section of the Plant Operations Division.

Special care must be taken in packaging; in some cases the container design may require the approval of the Bureau of Explosives. Accordingly, contact the Special Materials Department for packaging instructions each time a shipment is to be made. When completed, deliver the package to them for shipment.

Off-site shipments of radioactive materials must be made in accordance with the regulations of the Interstate Commerce Commission. The Special Materials Department is thoroughly acquainted with these rules and has been made responsible by the Laboratory for such shipments.

Special Materials also maintains the special material inventories which must be controlled with extreme care. 
8

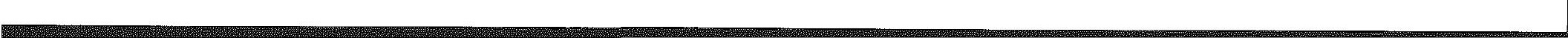


IV. RADIOACTIVITY AND HAZARDS

\section{A. Nature of Radiations}

Any material which spontaneously emits an ionizing radiation is defined as a radioactive material. Naturally occurring radioactive substances emit one or more of three types of radiations, namely alpha, beta, and gamma rays. In addition, some artificially prepared radioelements emit positrons. Neutrons are emitted by spontaneously fissionable materials and from sources such as radium and beryllium in combination. Neutrons are usually present in the neighborhood of reactors.

Alpha particles are doubly charged helium ions, which have a very weak power to penetrate objects. They are completely absorbed by a few sheets of paper or by the outer layers of the skin: however, they are able to produce marked ionization of gases through which they pass. Because the penetrating power of alpha particles is limited, they do not present serious problems as long as they are kept out of the body, but if ingested or inhaled, some alpha emitters, such as radium or plutonium, tend to accumulate in the body where their continued action may be harmful. In general, those elements which emit alpha particles have atomic weights in excess of 200 .

Beta rays or electrons are roughly 100 times more penetrating than alpha particles: thus, they can penetrate a few millimeters of body tissue. Their ionizing power is appreciably less than that of alpha radiation. Electrons of the energy range usual for radioisotopes (about $1 \mathrm{Mev}$ ) lose their energy mainly by direct ionization.

The positron is physically similar to the electron, except for its positive charge. Although the positron has an average life of $10^{-9} \mathrm{sec}$. its annihilation is accompanied by the emission of intense gamma radiation. Accordingly, for purposes of radiation safety, positron sources should be treated carefully.

Gamma rays offer a serious hazard. They are electromagnetic radiations of extremely short wave lengths (about $10^{-10} \mathrm{~cm}$ ) corres= ponding to $X$ rays of very high energy. They are extremely penetrating, being able to enter deeply into the body. The gamma rays lose energy by processes of pair production, Compton scattering, and the production of photoelectrons.

Neutrons are particles of about unit mass (on the atomic weight scale). They have no charge and they do not produce directly any appreciable ionization in their travels, but do so indirectly through the 
production of charged nuclei. The absence of charge gives neutrons very high penetrating power: like gamma rays, they can pass through the skin and enter the tissues.

\section{B. Biological Consequences Resulting from Radiation}

The harmful effects of radiation are due essentially to their ionizing effect on living tissues. A striking characteristic of the biological effects of ionizing radiation is the long delay that may occur between the exposure and the manifestation of the effect.

The distribution of the ionization in tissue varies markedly with the type of radiation. Thus, electrons incident on the body from external sources will penetrate a distance of only a few millimeters; on the other hand, those electrons produced in the body by the action of gamma rays will be distributed more or less uniformly throughout the tissue. In general, damage will be still greater from recoil protons produced on the entrance of neutrons into the tissue.

All tissues of the body are susceptible to radiation damage. In particular, those tissues which are responsible for the formation of blood are highly sensitive, and exposure to radiation may depress new blood cell formation. The brain and the retina of the eye are fairly radioresistant, but blindness may be produced by large doses of radiationdelivered to the lens of the eye. Cataracts have occurred in the eyes of individuals several years after exposure to fast neutrons such as are produced in the cyclotron and nuclear reactors.

The reproductive organs are also sensitive to irradiation. Temporary or permanent sterility may result when these organs, or the entire body, are subjected to sufficient radiation.

Active materials may enter the body through the mouth, nose, skin, or wounds. These materials lead to internal irradiation, which may be contrasted with external irradiation. The location of the source of radioactivity is the only difference between external and internal radiation. In one case, the source is located outside of the body; in the other, it is inside the body.

The degree of injury to cells depends upon a multiplicity of factors, including the type and quantity of radiation. The total exposure received will be the sum of the external and internal radiation, as measured in rads.

Internal radiation may be a greater hazard than exposure to external radiation. With some isotopes it is often especially dangerous because of their potentiality for producing delayed effects. Exposure to 
external radiation is usually for a limited period of time and generally is easily controlled by regulating the effective distance (including shielding) between the individual and the source. On the other hand, when radioactive material is present in the body, irradiation is continuous until the source is eliminated or decays.

The time required by the body to eliminate one-half of a given dose of active material is called the biological half-life. In some cases when the biological half-life is very long it is extremely difficult, if not impossible, to increase the rate of active material elimination. Sources within a body are in intimate contact with the tissues. Accordingly, while it is relatively easy to eliminate dangers of alpha and beta radiations from external sources because of their limited penetrating power, the damage caused by such radiations within the body can be significant.

If an active gas, vapor, spray, or dust is inhaled, a large fraction may be retained by the lungs, subjecting them to direct irradia tion. From the lungs, material may be absorbed directly into the bloodstream, thereby permitting transmission to all parts of the body. If the material is partially eliminated from the lungs by the swallowing of sputum, examination of the feces may detect the radioactive material if it is not absorbed appreciably by the intestine.

In addition, active materials may be ingested by drinking from a contaminated container or by placing contaminated objects (such as the hands, food, cigarettes, lipstick, etc.) into the mouth. This will lead to direct irradiation of the digestive organs and may be followed by absorpm tion into body tissues through the gastro-intestinal tract. Once activity has entered the body and has been deposited in the internal organs, it may be difficult to increase the natural rate of elimination.

Radioactive materials absorbed through an open wound may pass to any or all portions of the body via the blood and give rise to the same types of problems as outlined above.

C. Radiation Units

Roentgen $(\mathbf{r})$

The quantity of $\mathrm{X}$ or gamma radiation such that the as sociated corpuscular emission will produce one esu of charge (corresponding to $2.08 \times 10^{9}$ ion pairs) of either sign in one cc of air at standard conditions. This indicates the absorption of 83 ergs per gram of air.

Milliroentgen $(\mathrm{mr})-1 / 1000$ of a roentgen, that is, $1 \mathrm{mr}=0.001 \mathrm{r}$ 
Roentgen Equivalent Physical (rep) -

Roentgen Equivalent $\operatorname{Man}($ rem) -

Curie (c) -

${ }^{" 6} \mathrm{M}^{39}$

Relative Biologic Effectiveness (RBE) -

rad -
That quantity of ionizing radiation which will result in the absorption in tissue of 93 ergs per gram.

That quantity of radiation which, when absorbed in tissue, produces a biom logical effect equivalent to the absorption by man of one roentgen of $\mathrm{X}$ or gamma rays.

The quantity of any radioactive substance in which the number of disintegrating atoms is $3.7 \times 10^{30}$ per sec.

The term " $M$ " is used to indicate alpha contamination and designates thousands of disintegrations per minute per $100 \mathrm{~cm}^{2}$ of probe coverage.

The ratio of $\mathrm{X}$ or gamma-ray dose to the dose that is required to produce the same biological effect by the radiation in question.

That quantity of radiation which will result in the absorption in any medium of 100 ergs per gram.

\section{Permissible Exposure Levels}

All unnecessary exposure to radioactivity must be avoided. Anyone working with radioisotopes will necessarily be subjected to some radiation, but small exposures are harmless.

In order to define "small" amounts in each case, Argonne National Laboratory has adopted the values of maximum permissible levels of exposure established by the National Bureau of Standards, Handbook 52, "Maximum Permissible Amounts of Radioisotopes in the Human Body and Maximum Permissible Concentrations in Air and Water," and Handbook 59, "Permissible Dose from External Sources of Ionizing Radiation." These values serve as guides to safe operation and represent upper levels of exposure. They are not meant to be "tolerances," that is, denoting no damage whatever. Rather, they are meant to serve as permissible exposures which, in the light of present knowledge, are not expected to cause appreciable damage to a person at any time during his lifetime. Every reasonable effort (through the use of shielding, remote control 
devices, masks, protective clothing, etc.) is to be employed in order to minimize the amount of radiation exposures. Health Division and Industrial Hygiene and Safety Division personnel are available at all times to advise on protection problems.

In general terms, there are different limits to the amount of external exposure depending on the type of radiation.

In Table I are listed maximum permissible concentrations of unknown radioisotopes in the air and in water. These values are believed to be safe for exposure for periods of a few months. This Table is to be used as a guide only when the gross activity and not the specific emitter is known.

Table I

\section{PROVISIONAL LEVELS OF PERMISSIBLE CONCENTRATION OF RADIOACTIVE CONTAMINANTS}

Medium in which Contaminant
is Contained

Air

Water

$\frac{\begin{array}{c}\beta \text { or } \gamma \text { Emitter } \\ (\mu \mathrm{c} / \mathrm{ml})\end{array}}{10^{-9}}$

$10^{-7}$ $\alpha$ Emitter $(\mu \mathrm{c} / \mathrm{ml})$

$5 \times 10^{-12}$

$10^{-7}$

Table II lists the most common alpha emitters along with recommended standards for maximum permissible concentration in air and water for continuous exposure. Table III lists similar information for the most common beta-gamma emitters.

The levels listed in Table II and III are estimated to be safe for long periods of time. Thus, the maximum permissible level for plutonium in the atmosphere is set at $2 \times 10^{-12} \mu_{\mathrm{c}} / \mathrm{ml}$, corresponding to about $3 \times 10^{-11} \mu \mathrm{g} / \mathrm{ml}$. In this case the purpose is to prevent the deposition of more than 0.008 microcuries of plutonium in the body during a person's lifetime. The levels in other cases have been set for similarly appropriate reasons.

The maximum permissible total body exposures for external radiation are listed in Table IV, while the maximum permissible neutron. flux densities are listed in Table $\mathrm{V}$. 
Table II

MAXIMUM PERMISSIBLE EXPOSIRE AND OPERATING LEVELS FOR SOME ALPHA EMITTERS

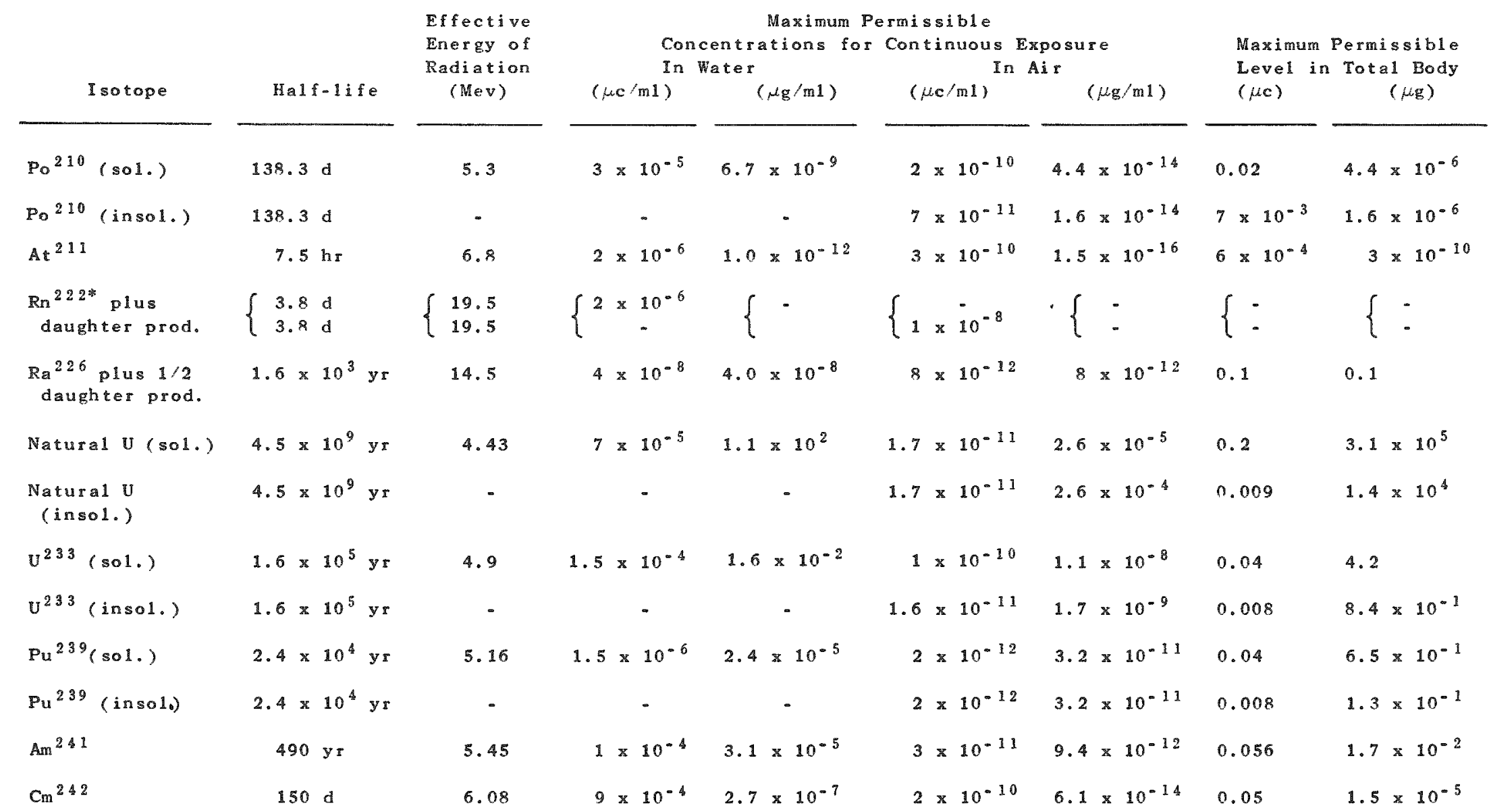

* Two values are given for the maximum permissible levels in total body since they are calculated to give (0.31 RBE) $\mathrm{rep} /$ week exposure to a critical organ. In some instances the isotope may appear in either of two organs; hence, two maximum permissible levels are given. Factors leading to the appearance of the isotope in greater concentration in one of two organs are (1) the chemical and/or physical form and properties of the isotope and (2) the biological half$1 \mathrm{i} f \mathrm{e}$ of the isotope in each organ. 
Table III

MAXIMLM PERMISSIBLE EXPOSURE AND OPLRATING LEVELS FOR SOME BETA AND GAMMA FMITTERS

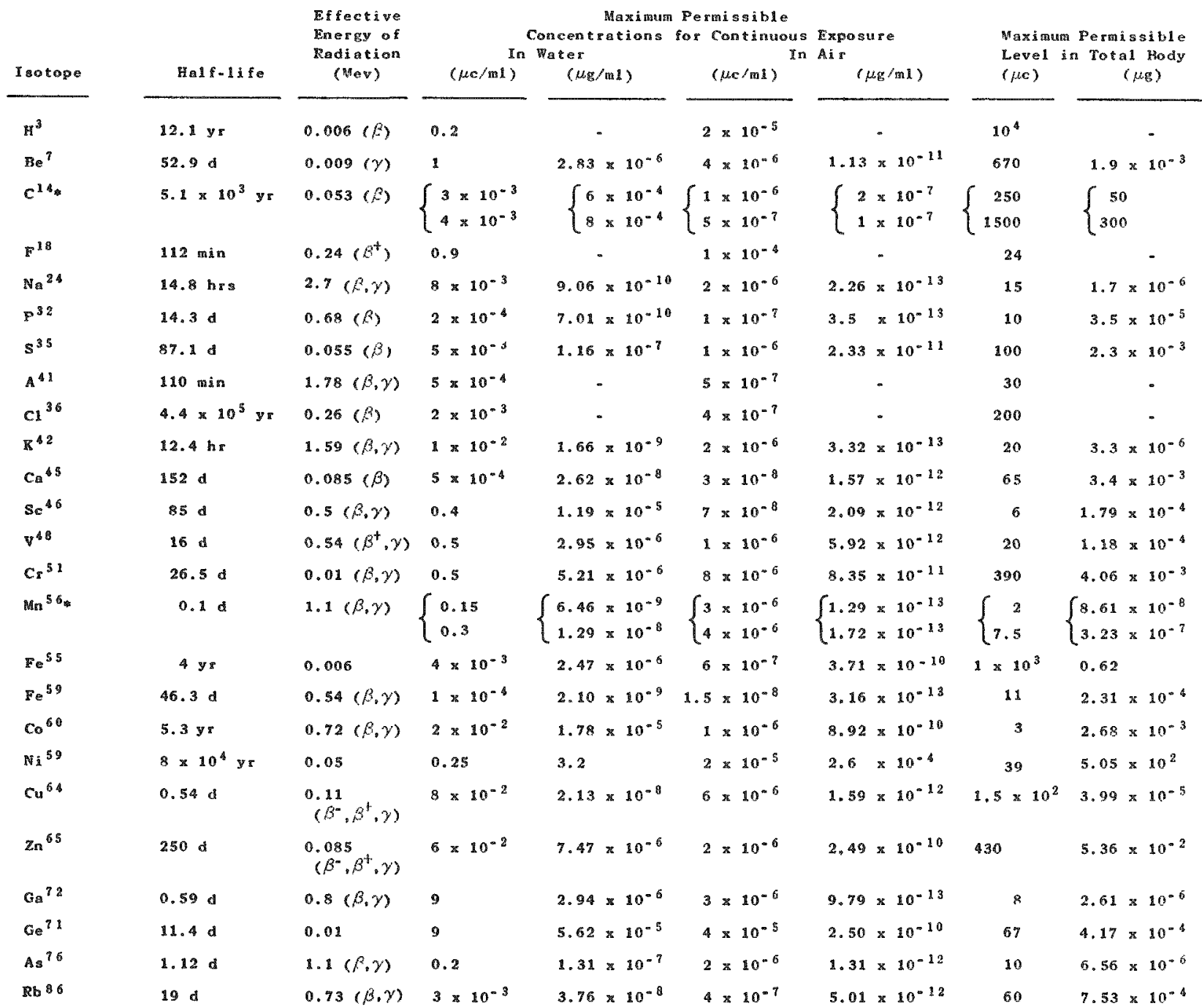

mTw values are given for the maximum permissible levels in total body since they are caleulated to give (0.31 fire) rep weels exposure to a citical organ. In some instances the isotope msy appeas in either of two organs; hence, two maximu pei missible levels are given. Factors leading to the appeasance of the isotope in greater concentration in one of two organs are (1) the chemical and/or physical form and properties of the isotope and (2) the biological half-life of the isotope in each organ. 
Table III (Contd.)

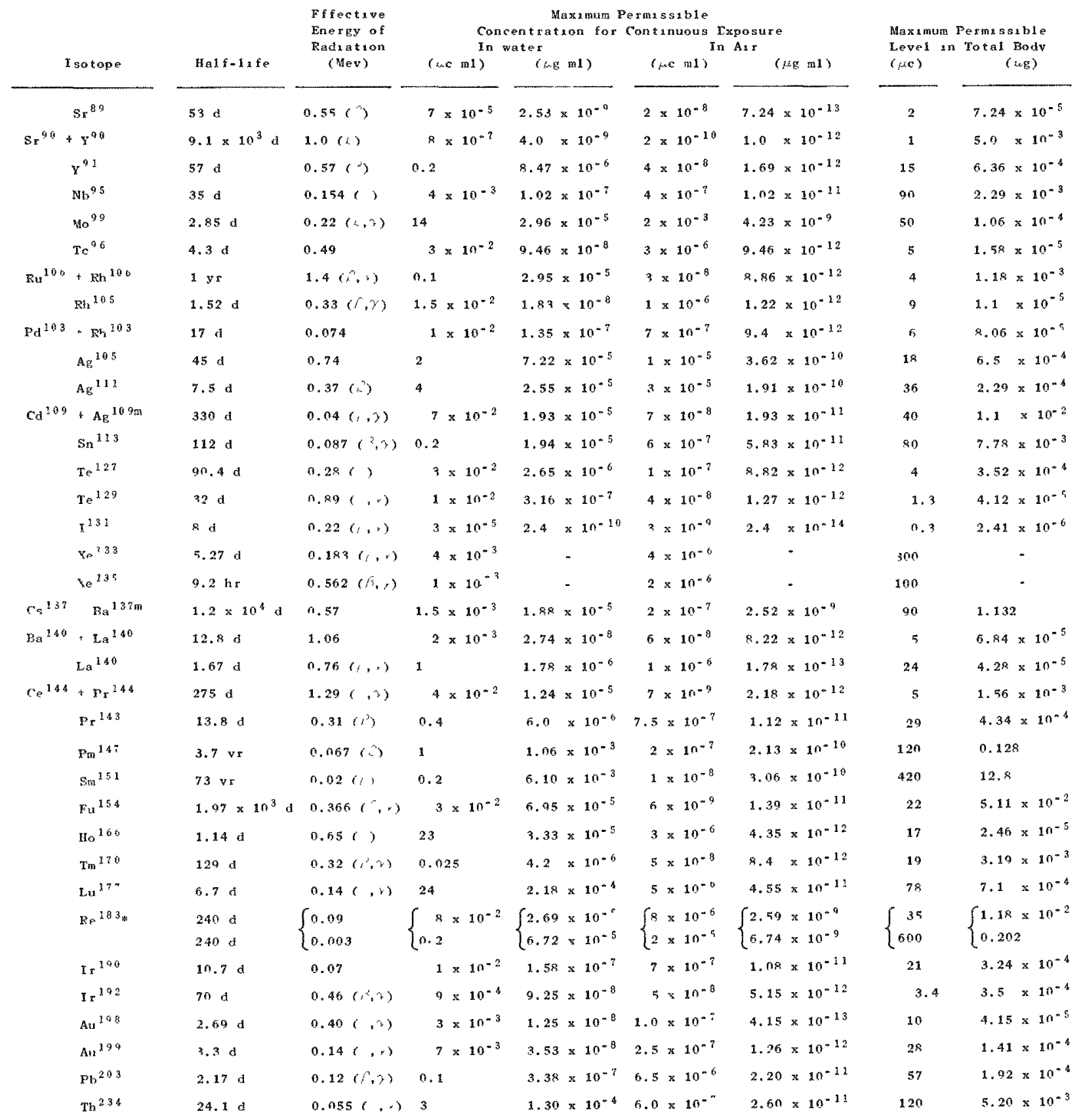


Table IV

MAXIMUM PERMISSIBLE EXPOSURES FOR EXTERNAL RADIATION (Total Body Exposures)

Type

$X$ Rays and Gamma Rays

Beta Rays

Beta and Gamma (sum)

$\mathrm{X}$ Rays (below 15-kv average)
Dose

$300 \mathrm{mr} /$ week

$500 \mathrm{mrep} / \mathrm{week}$

$500 \mathrm{mrep} /$ week

$500 \mathrm{mr} /$ week

\section{Table V}

MAXIMUM PERMISSIBLE NEUTRON FLUX DENSITIES

\begin{tabular}{cc} 
Energy (Mev) & $\mathrm{n} / \mathrm{cm}^{2} / \mathrm{sec}$ \\
\cline { 2 - 2 } 10 & 30 \\
5 & 30 \\
4 & 30 \\
3 & 30 \\
2 & 40 \\
1 & 60 \\
0.5 & 80 \\
0.1 & 200 \\
0.01 & 1000 \\
$10^{-5}$ & 1000 \\
$2.5 \times 10^{-8}$ (thermal) & 2000
\end{tabular}

E. Special Isotope Hazards

Severe radiation hazards are associated with those isotopes that have unfavorable combinations of half-life, high uptake, deposition in small organs or in bone, and low elimination rates from the body. Those 
isotopes which can be extremely dangerous as a result of intake into the body are: $\mathrm{Ca}^{45}, \mathrm{Fe}^{55}, \mathrm{Sr}^{90}, \mathrm{Y}^{91}, \mathrm{Zr}^{95}, \mathrm{Ce}^{144}, \mathrm{Pm}^{147}, \mathrm{Bi}^{210}$, and the alpha emitters.

It is possible to produce radiation hazards which are greater than the sum of those inherent in the individual radioisotopes. One way of doing this is by making chemical or physical mixtures containing one or more radioisotopes which result in nuclear reactions. An example is the $F^{19}(\alpha-n) \mathrm{Na}^{22}$ reaction, which may occur when working with the fluorides of heavy metals. This reaction may yield large neutron and gamma dosages to the hands of anyone handling heavy metal fluorides. The techniques used in handling such fluorides must be carefully evaluated. Other mixtures which result in the production of neutrons $(\alpha-n$ or $\gamma=n$, reactions) must be treated with similar care. Common examples of such mixtures are radium-beryllium, polonium-beryllium and antimony-beryllium.

\section{F. Preventing Contamination}

Constant vigilance to prevent contamination or to contain its spread must be exercised by every employee. Protection of the health of all personnel is of prime concern, but it is also important to maintain uncontaminated equipment and working areas, if precise and reliable counting data are to be obtained. Be particularly careful when you go from an active area into an area where personnel normally do not work with radioactive materials. Check your hands and shoes frequently. Change clothes if necessary. Utilize the hand and foot counters to prevent spreading contamination into other parts of the laboratory or even outside of the laboratory.

\section{G. Bibliography}

Journals and Periodicals

1. Evans, R. D., Radioactivity Units and Standards, Nucleonics 1, No. 2, 32(1947)

2. Craver, B. N., Radioactive Emanations: Their Nature, Mechanism of Action, Biological Effects and Tolerance Limits, J. Ind. Hyg. and Toxicol. 29, No. 3, 196 (1947)

3. Sullivan, W. H. Control of Radiation Hazards, Chem. and Eng. News 25, No. 26, 1893 (1947) 
Reports

1. Parker, H. M., Health Physics, Instrumentation and Radiation Protection, MDDC-783, March 25, 1947 (declassified)

2. Wirth, J. E., General Rules and Procedures Concerning Activity Hazards, MDDC-247, August 20, 1946 (declassified)

3. Cantril, S. T., Biological Bases for Maximum Permissible Exposure, $\mathrm{CH}-3571$, August 9, 1946 (declassified)

4. Morgan, K. Z., Tolerance Concentration of Radioactive Substances, $\mathrm{CH}-2801$, January 31,1945

5. Cantril, S. T., Safety Rules and Procedures Concerning Activity Hazards, CH-1864, June, 1944

6. Parker, H. M., Physical Aspects of the Effects of Beta Radiation on Tissue, CH-930, September 10, 1943

7. Radiation and Its Biological Effects, Project Handbook CL-697, Vol. IV, Ch. 12

Handbooks

1. National Bureau of Standards Handbook 59, Permissible Dose from External Sources of Ionizing Radiation,

(September 24, 1954)

2. National Bureau of Standards Handbook 55, Protection Against Betatron-Synchrotron Radiations up to 100 Million Electron Volts, (February 26, 1954)

3. National Bureau of Standards Handbook 52, Maximum Permissible Amounts of Radioisotopes in the Human Body and Maximum Permissible Concentrations in Air and Water, (March 20, 1953)

4. National Bureau of Standards Handbook 51, Radiological Monitoring and Instruments, (April 7, 1952)

5. National Bureau of Standards Handbook 47, Recommendations of the International Commission on Radiological Protection and the International Commission on Radiological Units, (June 29, 1951) 
Textbooks

20

1. Radiation Biology, A. Hollaender (Ed.), McGraw-Hill, New York, 1954

2. Industrial Medicine on the Plutonium Project, Robert S. Stone (Ed.). NNES, Series IV, Vol. 20, McGraw-Hill, New York, 1951 
21

V. PRECAUTIONS IN HANDLING RADIOACTIVE MATERIALS

A. Introduction

1. Protection from External Radiation

The best protection against external radiation is distance. Radiation intensity from a point source follows the inverse square law, which states that the intensity decreases as the square of the distance. One of the first things to do when working with radioactive material is to determine the level of activity involved. If it is necessary to remain near the radioactive materials, erect a barrier, the nature and thickness of which should depend on the type, energy and intensity of the radiation. Before starting construction, consult Radiation Safety regarding your choice of shielding materials. Tongs and other remote handling devices are helpful in increasing the distance from the source; their use also makes it possible to reduce the amount of shielding necessary.

External radiation dosage is also dependent on time. Work with radioactive materials should be completed as quickly as possible. Before beginning an experiment, prepare a complete plan of action; strive for the most efficient operation and the lowest possible total exposure. It is good practice to rehearse a dry run before proceeding with the actual experiment involving radioactive material.

\section{Protection from Internal Irradiation}

Radioactive materials must be kept out of the body. To accomplish this, do not eat, drink, or smoke in the vicinity of radioactive materials. Do not allow laboratory items, such as pipettes, glassware, tubing, etc., to touch the mouth. Wear proper respiratory equipment whenever there is a possible inhalation hazard. Use either an assault mask or equipment such as a Scott Air-Pak. The assault mask has a highly efficient filter for particulate matter and a canister which absorbs vapors and gases. The Scott Air-Pak is a self-contained air unit. Although both types of equipment are effective, the Scott Air-Pak is preferred for protection from airborne radioactive material which may be inhaled. The Air-Pak does not rely on cleaning the air; instead, it provides air which is entirely separate from the room air. Furthermore, a positive pressure can be supplied to the facepiece of the Air-Pak thereby eliminating the possibility of leakage during inspiration.

Use dry boxes to keep radioactive dusts to a minimum.

Wash the hands thoroughly before eating, smoking or leaving work. Extreme personal cleanliness is a necessity. Utilize the available 


\section{2}

hand and foot counting facilities frequently to check for contamination. Above all, use common sense; do not let familiarity breed contempt for the precautions necessary for safety.

Report any cuts or skin lesions at once to your Supervisor. If the cuts or skin lesions occur while working with radioactive materials, have the wounds surveyed by Radiation Safety personnel and then report to the Health Division for treatment. Under no circumstances should such a wound be self-treated; however, immediate action should be taken to remove possible contamination. Wash the wound under large volumes of running water, spreading the edges of the cut to permit flushing action by the water. All wounds are to be reported to the Health Division as soon as emergency procedures have been taken. The emergency procedures are followed in order to prevent contamination from entering the system in the time interval that is required to obtain Health Division's services.

It is emphasized that skin diseases and cuts received away from work, as well as those originating in the Laboratory, increase the probability of absorption of radioactive materials. Never work with high levels of activity if you have cuts or abrasions.

\section{Precautions with Regard to Beams from Reactors and Accelerators}

The best protections from beams generated by reactors and accelerators are adequate distance and minimum exposure time. Per manent shielding has been built around the reactor. When beam holes are opened for experimental work, beam catchers must be used and the area monitored by Radiation Safety personnel. Rope off areas around open beam holes. In the case of the cyclotron, no one is permitted into the room or vault when the machine is operating. In the experimental area of the van de Graff, the directions of the operators must be obeyed implicitly.

\section{General Housekeeping Methods}

Make every effort to keep working and storage areas clean, unclutiered, and free of contamination. Use stainless steel trays, uncracked glass plates, and/or other impervious material to cover surfaces which may become contaminated. Kraft-backed paper may be used, but it must be discarded frequently to prevent loose active materials from dust ing off the surface. Industrial tape, which may be stripped easily and disposed of should it become contaminated, is useful for lining areas such as hood walls. Cover exposed metallic surfaces of equipment with strippable paint, such as Pyroxcotte. This will facilitate decontamination procedures. Consult the Decontaminable Surfaces Committee (call Reclamation Section of the Plant Operations Division) for advice on special problems. 


\section{3}

Wherever possible, vessels containing active solutions are to be kept in secondary containers. Chemically inert absorbent material may be used as filler to prevent the spread of activity in case the prime container breaks.

\section{Monitoring and Surveying}

All laboratories are monitored routinely by Radiation Safety personnel to measure radiation levels and to detect and measure any contamination flloors, tables, and other surfaces. Reports of surveys are either posted at the areas involved or sent to the appropriate personnel. In addition to the routine surveys, special surveys are sometimes necessary. These may be done either by the laboratory occupant or by Radiation Safety personnel. The instruments available for such purposes are listed in Appendix III. Seek instruction from your Group Leader or from Radiation Safety as to the proper use of these devices. These individuals will also help you select the proper instruments. When making surveys, try to establish what isotopes are involved. These are generally known from the operational history of the area; however, there may be cross-contamination from radioactive materials used in nearby areas. If there is any uncertainty, have the isotopes determined by assays. For information concerning assays, consult the local representative of Radiation Safety. If contamination is found, start decontamination promptly. Carefully inspect shielding for contamination and for possible radiation leaks. Upon request, Radiation Safety will monitor your area and advise on decontamination problems.

\section{Preventing Spread of Contamination}

Contamination usually presents a serious problem. If undetected or not properly removed, radioactive substances may enter the body, be taken home, be spread to non-active portions of the Laboratory, or spoil precise experiments in other laboratories. Thus, every effort must be made to detect contamination and to prevent its dispersal. Inasmuch as the hands and shoes are especially vulnerable, it is wise to use rubber gloves and special shoes or protective shoe coverings. In addition, wear protective laboratory coats or coveralls in locations where clothing may become radioactively contaminated. Do not wear the protective clothing outside the working area.

Use the hand and foot counters, which are located throughout the Laboratory, frequently. Be especially careful to take a hand and foot count each time you leave an active area. Outer clothing used in active laboratories is not to be worn in nonactive areas. Exceptions to this rule may be established by the Supervisor with the approval of the Radiation Safety representative. 


$$
24
$$

Neatness in the laboratory is a prime requisite for controlling contamination. Do not stockpile equipment and glassware in the laboratories. Clean the work areas frequently and survey them for activity. As a matter of routine, make surveys at the conclusion of each series of experiments before releasing the work area for other uses.

All work must be carried out on surfaces that are easily decontaminated. Cover the area of operations with stainless steel, glass trays or other impervious material.

All active solutions must be stored in secondary containers to prevent spread of contamination in case of breakage. Label all active solutions as to content, activity, date and responsible personnel. Discard wastes immediately in the proper disposal containers.

Items which have been in active areas must be kept out of the stockrooms. Tools and equipment which have been used in handling radioisotopes are regarded as contaminated until they are proved to be otherwise. Do not release them for non-active work nor permit them to be moved from the active area without having them surveyed.

All transfers of active material are to be made from person to person. Under no circumstances use the U.S. Mail or the Laboratory's mail services to ship active materials. Special Materials must be consulted for all transfers of radioactive materials and equipment, and Radiation Safety for all transfers of radioactive wastes or contaminated materials.

\section{Reporting Exposures}

If your film badge or dosimeter readings are ever above permissible levels you, your supervisor, and the Health Division are im mediately notified of the exposure. Thereafter, your health, your work area and your experimental procedures are reviewed and necessary corrective actions are taken. Records of area surveys and personnel exposures are maintained by the Radiation Safety group. Your current record is in the office of the Radiation Safety representative for your building where you may review it if you choose. Past records are in a central file and are available for review.

8. Special Facilities for Operations with Hazardous Levels

$$
\text { a. Building } 301
$$

Building 301 is provided with three high-level caves with sufficient shielding for several thousand curies of gamma radiation. 
One is a three-cell cave designed primaxily for metallographic operations. The other two single-cell caves are available to all the scientific divisions. These caves have been constructed of three-foot thick, high-density concrete shielding, and, for viewing purposes, are equipped with windows filled with zinc bromide solution. Master-slave manipulators have been installed in these caves to permit remotely controlled operations.

For scheduling and use of the facilities of Building 301, contact the Remote Control Division. Its staff will help you plan experiments and will provide equipment for the work to be done in the caves. A Radiation Safety representative is also available at all times for consultation on radiation safety problems.

\section{b. Building 40}

Building 40 contains facilities for performing chemical operations with high levels of activity. It contains one high-level cave which has steel walls six inches thick; ventilation adequate for most chemical operations; and an electronic manipulator for remote control operations. A junior cave, with three-inch steel shielding and a master-slave manipulator, is also available. In addition, several fume hoods have been provided for the handling of alpha-active material and for preparing reagents. Provision has been made for electric power for welding capsules and cylinders.

Contact the office of the Chemistry Division to schedule operations in Building 40 and to get help on particular problems. There is no staff available in this building; therefore, all manpower will have to be provided by the requestor. Inasmuch as the structure is remotely situated with respect to other buildings, it is strongly recommended that no one work alone in Building 40 at any time.

\section{B. Precautions in Handling Alpha-Active Materials}

Pay close attention to well-planned techniques and good housekeeping when you handle alpha-active materials. Keep clothing, personal possessions, hands, face, etc., well below 100 alpha disintegrations per minute per $100 \mathrm{~cm}^{2}$. If the hand count ever exceeds this value, start decontamination procedures immediately. Protective clothing and shoes having more than 1000 alpha disintegrations per minute must be decontaminated immediately and must not be worn outside the laboratory area.

Loose alpha contamination on floors, table tops and laboratory equipment is to be maintained below 100 alpha-disintegrations per minute per $100 \mathrm{~cm}^{2}$. This rigid limit has been set because 100 se alpha particles on these surfaces may be easily brushed into the air where they become an inhalation hazard. 
1. The Use of Hoods and Dry Boxes

Hoods and dry boxes are protective devices used to confine radioactive materials. The rate of intake of air into hoods should be sufficiently high to keep contaminated air out of the room; yet it must not be too high so that small light articles are upset by the moving air. A hood face velocity of 100-150 lineal feet per minute is recommended. Every worker must become throughly familiar with the hood controls available in order to maintain proper flow rates at all times. When hazardous levels of alpha activity are employed, it is important to check the flow rate during the course of an experiment. Routine flow checks are made by building maintenance personnel. For special services, contact the Plant Operations Supervisor for the area or building.

When solutions containing alpha emitters are heated, the operation must always be carried out in a well-ventilated hood, approved for such use, regardless of the concentration of the emitter. During the evaporation of active solutions, the alpha air count often increases markedly, even when there is no visible gas evolution. Upon request, Radiation Safety personnel will take air samples and notify you of the results.

Manipulate active dry compounds in approved hoods or dry boxes. Alpha-active materials should be outside the hood or box only when in a safe secondary container. If the material is pyrophoric, the container should be non-combustible.

Use glass or tile plates, stainless steel trays, plastic strips, or other impervious material to line hoods to make decontamination as easy as possible. Stainless steel trays are generally excellent for catching spills of active solutions. If large amounts of alpha-active materials are to be handled, use a closed glove hood that contains the necessary tools and equipment and is fitted with exterior controls. Be certain that the pressure of the enclosure is less than that of the room. This is of particular importance when there is any danger of radioactivity getting into the air from sprays, gas evolution, or as a dust from sawing operations. Radiation Safety should be requested to monitor all large scale operations.

\section{Use of Respiratory Equipment and Protective Clothing}

Wear protective clothing, such as laboratory coats or coveralls and shoe covers, whenever there is a possibility that your personal clothing may become contaminated. Remove the protective clothing before you leave an active area. This will help prevent the spread of activity to other parts of the Laboratory. If you suspect that your protective clothing is contaminated, request Radiation Safety to make 
immediate check. It is your responsibility to wear protective clothing. There is no mechanism whereby you can be reimbursed by the Laboratory for contaminated personal articles and clothing.

Wear rubber gloves if it is possible that your hands may become contaminated. The proper technique for putting on and removing surgical gloves, so that inside surfaces will not become contaminated, is described in Appendix I. Even though gloves are worn, handle contaminated objects wherever possible with paper towels or disposable tissues. Once used, treat the gloves as though contaminated unless the contrary is revealed by survey.

In general, face shields are to be worn during manipulations with active solutions. Specifically, they must be used during any plating or pipetting operations or where any danger of splattering exists.

Wear safety glasses when working in any location where there is an apparent eye hazard. They may be obtained through your group leader. The Laboratory will provide prescription-ground safety glasses without cost to you.

Wear an approved respiratory device whenever there is a possibility of inhaling radioactive materials. Alpha emitters may be hazardous if inhaled. Use either an assault mask or equipment such as a Scott Air-Pak. The assault mask has a highly efficient filter for particulate matter and a canister that absorbs vapors and gases. The Air-Pak is a self-contained air supply unit. Although both types of equipment are effective, the Air-Pak is preferred for protection from airborne radioactive material which may be inhaled. The Air-Pak does not rely on cleaning the air; instead it provides air which is entirely separate from the room air. Furthermore, a positive pressure can be supplied to the face piece of the Air-Pak, thereby eliminating the possibility of leakage during respiration. The type of respiratory equipment to be used in any particular operation must receive the prior approval of Radiation Safety. When work involving airborne alpha activity is completed, ask Radiation Safety to run air surveys to determine if it is necessary to continue to wear respiratory equipment. After use, all respiratory equipment must be sent to Radiation Safety. Under no circumstances return respiratory devices to storage.

3. Care to be Taken in Pipetting, Centrifuging, and Glass Blowing

Pipettes, glassware, tubing, and similar items of laboratory equipment must never be allowed to touch the mouth. No solution, regardless of its nature, is to be pipetted by mouth. A syringe, rubber bulb, or other approved device must be used. No distinction is made 


$$
28
$$

between active and inactive material. Active solutions are not to be transferred by pouring. Distillates from active solutions must be condensed and collected.

Check the ventilation before centrifuging. Centrifuges used for alpha-active materials must either be located in hoods or be equipped with exhaust pipes which lead directly to the building exhaust system. Check all tubes by spinning them with water before using them to centrifuge active solutions.

In laboratories where alpha-active materials are handled, glass blowing and the supply of glass tubing must be kept to a minimum. Obtain glass tubing from the stockroom as it is needed. Survey the un used portion for contamination. If it is free of contamination, store it in a special cabinet; if contaminated, discard it as active waste. Obtain new rubber tubing from the stockroom every time you blow glass. Never blow glass with tubing that has been used for other purposes or has been stored in an open laboratory.

Do everything in your power to keep the glass shops free from contamination. Even a small amount of contamination might spoil a fellow worker's precise experiment or endanger the health of a glass blower. If glassware has been in an active area, do not take it to the glass shop unless permission to do so has been granted by the glass shop personnel.

\section{Disposal of Alpha-Active Wastes}

Notify Radiation Safety whenever you place greater than microcurie quantities of alpha-active material in a dry active waste can. This is important in order to assure safe handling of the waste.

Retain liquid active samples for disposal by the Reclamation Section. Do not discard active wastes down drains. Place solutions in liquid waste containers which will be provided on request by the Reclamation Section. Keep aqueous wastes separate from organic liquid wastes.

At the present time there is no routine method for liquid active waste disposal at the Idaho Division site. Consult your Radiation Safety representative whenever you have a disposal problem.

\section{Disposal of Contaminated Equipment}

Wrap and seal heavily contaminated articles of clothing in vinyl sheeting. Contact Radiation Safety for disposal. If you have 


\section{9}

contaminated equipment that is too large for dry active waste can disposal, request Radiation Safety to survey it. Then wrap and seal it in vinyl sheeting to prevent radiation hazards which result from the formation of active dusts. Contact Radiation Safety regarding its disposal.

If the equipment is to be decontaminated and reclaimed, Radiation Safety will initiate the necessary work orders.

\section{Neutron Hazards from Alpha Emitters}

It is possible to produce radiation hazards which are greater than the sum of those inherent in the individual radioisotopes. One way of doing this is by making chemical or physical mixtures containing one or more radioisotopes which result in nuclear reactions. An example is the $\mathrm{F}^{19}(\alpha-n) \mathrm{Na}^{22}$ reaction, which may occur when working with fluorides of heavy metals. This reaction may yield large neutron and gamma dos ages to the hands of anyone handling heavy metal fluorides. The techniques used in handling such fluorides must be carefully evaluated. Other mixtures which result in the productions of neutrons $(\alpha-n$ and $\gamma-n$ reactions $)$ must be treated with similar care. Common examples of such mixtures are: radium-beryllium, polonium-beryllium, antimony-beryllium.

\section{Precautions in Handling Beta- and Gamma-active Materials}

Keep beta-gamma contamination on the hands, face, clothing, etc. well below $0.1 \mathrm{mr} / \mathrm{hr}$ at $\mathrm{l}$ inch, and keep shoe counts (as measured by a Laboratory foot counter) below 5000 counts/min. If these levels are exceeded, start decontamination procedures at once.

The Health Division and the Radiation Safety Section have recommended that all laboratory equipment, floors, hoods, etc., be maintained below $7.5 \mathrm{mr} / \mathrm{hr}$ at 1 inch. Areas above $7.5 \mathrm{mr} / \mathrm{hr}$ at one inchmust be shielded or posted in order to prevent over-exposure of laboratory personnel. The maximum permissible level for continuous (40 hours per week) personnel exposure is $7.5 \mathrm{mr} / \mathrm{hr}$.

\section{Protection from External Radiation}

\section{a. Hot Hoods}

Not all the hoods throughout the Laboratory are equipped with filters for use with radioactive materials. The Radiation Safety Section has identified all unfiltered hoods which must not be used for operations involving activity. 
b. Shielding

All operations with beta-gamma active materials must be performed behind adequate shielding of sufficient thickness and axrangement so that the radiation level at the point of closest approach is within permissible limits. Check all material for possible contamination before using it as shielding.

For beta activity it is desirable to use material of Low atomic number to reduce Bremmstrahlung and scattered radiation. Sufficient protection is provided by $1 / 4-1 / 2$ inch of Lucite or $1 / 2-1$ inch of wood.

The Bremmstrahlung effect is appreciable when high activity concentrations, i.e., greater than $100 \mathrm{mc}$, are being shielded. Depending on the beta energy and on the atomic number of the shielding medium, up to $10 \%$ of the energy may be converted to Bremmstrahlung rays. A convenient rule to follow is that the Bremmstrahlung hazard is about $1 \mathrm{mc}$ gamma equivalent for each curie of beta. If aluminum rather than lead is used to shield the active source, the Bremmstrahlung radiation will be reduced by a factor of about 6 .

The thicknesses of various metals sufficient to bring about a 2 -fold reduction (Half Thicknesses) in the intensity of gamma radiation of various energies are given in Figure $L$ and in Table VI.

From these values it is possible to deduce the thickness required for any degree of attenuation. The formula to be used is

$$
n=3.33 \log _{10}\left(I_{0} / I\right)
$$

where $n$ is the number of half thicknesses, $I_{0}$ is the original intensity of the gamma radiation, and $I$ is the desired intensity.

Arrange the shielding material to form four walls and a floor; in some cases a roof may be necessary. It is important that the shielding be adequate to protect personnel in adjacent areas. Mount the shielding so that it will not creep under its own weight. If necessary, provide additional bracing to support the weight of the shielding materials. Walls must be of sufficient height to protect the head of a worker standing at the point of closest approach. Make arrangements so that all operations may be viewed by means of mirrors without exposing the head. Shielding must be carefully planned. 


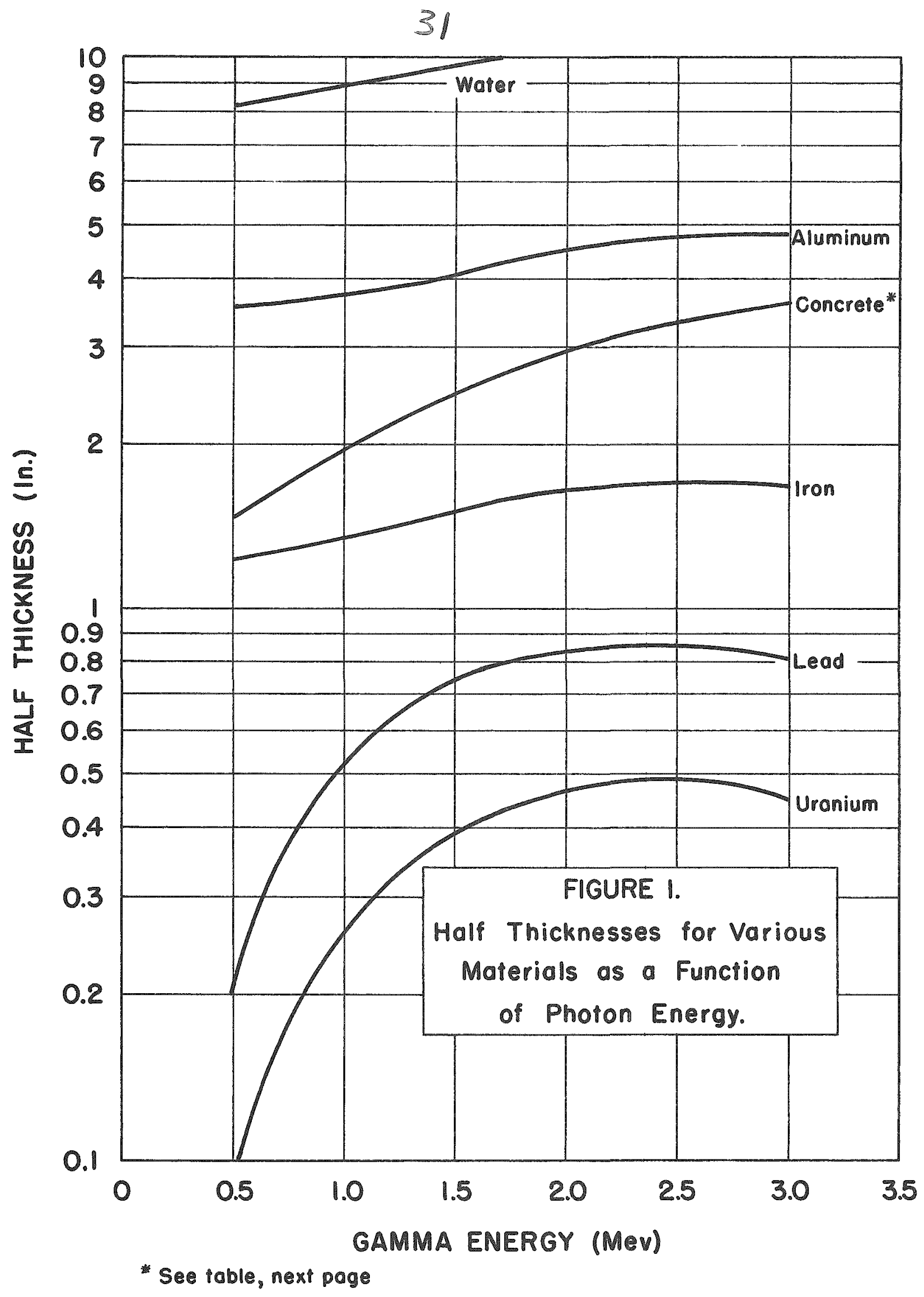


Table VI

HALF THICKNESSES IN INCHES FOR VARIOUS MATERIALS AT VARYING GAMMA ENERGIES

\begin{tabular}{|c|c|c|c|c|c|c|c|}
\hline $\begin{array}{l}\text { Energy } \\
\text { (Mev) }\end{array}$ & Water & Concrete* & Iron & Lead & Aluminum & Uranium & Air \\
\hline 0.5 & 8.28 & 1.46 & 1.225 & 0.200 & 3.550 & 0.0898 & 7,205 \\
\hline 0.6 & 8.33 & 1.56 & 1.267 & 0.279 & 3.540 & 0.1246 & 7,230 \\
\hline 0.7 & 8.43 & 1.66 & 1.290 & 0.349 & 3.550 & 0.1599 & 7,305 \\
\hline 0.8 & 8.56 & 1.76 & 1.314 & 0.414 & 3.589 & 0.1940 & 7,429 \\
\hline 0.9 & 8.70 & 1.86 & 1.319 & 0.478 & 3.680 & 0.2295 & 7,549 \\
\hline 1.0 & 8.83 & 1.96 & 1.349 & 0.534 & 3.750 & 0.2580 & 7.680 \\
\hline 1.2 & 9.22 & 2.16 & 1.396 & 0.632 & 3.940 & 0.3179 & 8,030 \\
\hline 1.4 & 9.58 & 2.37 & 1.462 & 0.717 & 4.120 & 0.3730 & 8,310 \\
\hline 1.6 & 9.88 & 2.60 & 1.532 & 0.777 & 4.255 & 0.4180 & 8,690 \\
\hline 1.8 & 10.23 & 2.82 & 1.581 & 0.815 & 4.380 & 0.4520 & 8,980 \\
\hline 2.0 & 10.58 & 2.99 & 1.634 & 0.840 & 4.500 & 0.4680 & 9,255 \\
\hline 2.2 & 10.83 & 3.12 & 1.672 & 0.845 & 4.560 & 0.4740 & 9,505 \\
\hline 2.4 & 11.10 & 3.24 & 1.681 & 0.845 & 4.645 & 0.4725 & 9,730 \\
\hline 2.6 & 11.37 & 3.36 & 1.681 & 0.843 & 4.710 & 0.4690 & 9,960 \\
\hline 2.8 & 11.62 & 3.48 & 1.666 & 0.836 & 4.775 & 0.4635 & 10,150 \\
\hline 3.0 & 11.87 & 3.59 & 1.657 & 0.817 & 4.820 & 0.4540 & 10,360 \\
\hline 3.5 & 12.40 & $=-$ & 1.591 & 0.781 & 4.929 & 0.4319 & 10,657 \\
\hline 4.0 & 12.87 & $-\infty$ & 1.542 & 0.744 & 5.051 & 0.4087 & 11,102 \\
\hline
\end{tabular}

* Coherent scattering not included in the calculations. Mass attenuation coefficients for concrete used. 


\section{3 \\ c. Remote Control Devices}

Use suitable tongs and other remote control devices wherever practicable. Long-handled tools provide good protection by distance where millicurie amounts of beta or gamma activity are involved; such items are available in the Chemistry Division. An extensive file of drawings for remote control devices is available in the Remote Control Division. Remote control devices are designed whenever new situations develop. Discuss your needs with the Remote Control Division.

\section{d. Storage and Disposal of Active Samples}

All containers of radioactive materials must be properly labeled as to their contents. Materials which emit beta and gamma rays must be adequately shielded to prevent excessive exposure.

Check the activity of solid active waste materials before placing them in a standard dry active waste can. If they will cause the level of radiation at the surface of the can to exceed $50 \mathrm{mr} / \mathrm{hr}$, request a shielded receptacle from Radiation Safety. Similarly, the radiation level at the surface of the usual liquid waste containers must be held to less than $50 \mathrm{mr} / \mathrm{hr}$. Request special liquid waste containers from Reclamation.

At the present time there is no routine method for liquid active waste disposal at the Idaho Division site. Consult your Radiation Safety representative whenever you have a disposal problem.

\section{e. Disposal of Contaminated Equipment}

Under no circumstances may contaminated equipment be stored in a laboratory or be returned to the stockroom. If the equipment is of such value that it should be reused, make arrangements for its storage in a safe location in accordance with local building regulations and with the approval of Radiation Safety.

Contaminated equipment which is no longer of any use may be discarded in the dry active waste can. If too large for such disposal, request a survey and disposal information from Radiation Safety.

If the equipment is to be decontaminated and reclaimed, make arrangements with Radiation Safety to initiate the necessary work orders. 
34

2. Protection from Internal Radiation

a. The Use of Hoods and Dry Boxes

Use adequately shielded hoods and dry boxes for operations with beta-gamma active materials whenever there is a possibility that the activity might escape.

The recommended rate of intake of air into hoods is in the range of 100-150 lineal feet per minute. Higher drafts may cause the upset of light articles; whereas smaller velocities may result in room contamination.

Request Radiation Safety to make a survey whenever there is reason to suspect that the room air may be contaminated. Use glass or tile plates, stainless steel trays, plastic strips, or other impervious material to line hoods to make decontamination as easy as possible. Stainless steel trays are generally excellent for catching spills of active solutions. Maintain dry boxes at a negative pressure.

b. Use of Respiratory Equipment and Protective Clothing

Wear protective clothing, such as Laboratory coats or coveralls and shoe covers, whenever there is a possibility that your personal clothing may become contaminated. Remove the protective clothing before you leave an active area. This will help prevent the spread of activity to other parts of the Laboratory. If you suspect that your protective clothing is contaminated, request Radiation Safety to make an immediate check. It is your responsibility to wear protective clothing. There is no mechanism whereby you can be reimbursed by the Laboratory for contaminated personal articles and clothing.

Wear rubber gloves if it is likely that your hands may become contaminated. The proper technique for putting on and removing surgical gloves, so that inside surfaces will not become contaminated, is described in Appendix I. Even though gloves are worn, handle contaminated objects wherever possible with paper towels or disposable tissues. Once used, treat gloves as though contaminated unless the contrary is verified by survey.

In general, face shields are to be worn during manipulations with active solutions. Specifically, they must be worn during any plating or pipetting operations or where any danger of splattering exists. 


\section{$\sum_{i=0}$}

Wear safety glasses when working in any locations where there is an apparent eye hazard. They may be obtained through your group leadex. The Laboratory will provide prescription-ground safety glasses without cost to you.

Wear an approved respiratory device whenever there is a possibility of inhaling radioactive materials. Beta and/or gamma emitters may be hazardous if inhaled. Use either an assault mask or equipment such as a Scott Air-Pak. The assault mask has a highly efficient filter for particulate matter and a canister that absorbs vapors and gases. The Air-Pak is a self-contained air supply unit. Although both types of equipment are effective, the Air-Pak is preferred for protection from airborne radioactive material which may be inhaled. The Air-Pak does not rely on cleaning the air; instead, it provides air which is entirely separate from the room aix. Furthermore, a positive pressure can be supplied to the face piece of the Air-Pak, thereby eliminating the possibility of leakage during respiration. The type of respiratory equipment to be used in any particular operation must receive the prior approval of Radiation Safety. When work involving airborne activity is completed, ask Radiation Safety to run air surveys to determine if it is necessary to continue to wear respiratory equipment. After use, all respiratory equipment must be sent to Radiation Safety. Under no circumstances return respiratory devices to storage.

\section{c. Care to be Taken in Pipetting, Centrifuging and Glass Blowing}

Pipettes, glassware, tubing, and similar items of laboratory equipment must never be allowed to touch the mouth. No solution, regardless of its nature, is to be pipetted by mouth. A syringe, rubber bulb, or other approved device must be used. No distinction is made between active and inactive material. Active solutions are not to be transferred by pouring. Distillates from active solutions must be condensed and collected.

Check the ventilation before centrifuging. Centrifuges used for radioactive materials must either be located in hoods or be equipped with exhaust pipes which lead directly to the building exhaust system. Check all tubes by spinning them with water before using them to centrifuge active solutions.

In laboratories where radioactive materials are handled, glass blowing and the supply of glass tubing must be kept to a minimum. Obtain glass tubing from the stockroom as it is needed. Survey the unused portion for contamination. If it is free of contamination, store it in a special cabinet; if contaminated, discard it as active waste. Obtain 


\section{$\rightarrow$}

new rubber iubing from the stockroom every time you blow glass. Never blow glass with tubing that has been used for other purposes or has been stored in an open laboratory.

Do everything in your power to keep the glass shops free from contamination. Even a small amount of contamination might spoil a fellow worker's precise experiment or endanger the health of a glass blower. If glassware has been in an active area, do not take it to the glass shop unless permission to do so has been granted by the glass shop personnel.

\section{d. Disposal of Active Samples}

Before disposing of any solid dust-producing betagamma active samples in dry active waste cans, they must be sealed in a container to prevent contamination of the air.

Retain liquid samples for disposal by the Reclamation Section. Do not discard active waste down drains. Place solutions in liquid waste containers which will be provided on request by the Reclamation Section. Keep aqueous wastes separate from organic liquid wastes.

Any liquid waste having an external radiation level greater than $50 \mathrm{mr} / \mathrm{hr}$ at the surface of the receptacle will require a shielded container, obtanable through the Reclamation Section.

At the present time there is no routine method for 1iquid active waste disposal at the Idaho Division site. Consult your Radiation Safety Representative whenever you have a disposal problem.

$$
\text { e. Disposal of Contaminated Equipment }
$$

The chief internal radiation hazard from equipment contaminated with beta-gamma active substances arises from dusts or gas emission. In storing, transporting, or otherwise disposing of such apiaratus, use protective packaging, such as vinyl sheeting, in order to prevent dust hazards. Seal the packages to prevent the escape of gases which may be radioactive or may carry radioactive dusts. Contact Radiation Safety for disposal.

\section{Neutron Sources}

\section{Protection from External Sources}

The shielding used during operations with neutron sources must be sufficiently thick and adequately arranged so that the radiation level at the point of closest approach is within permissible limits. Thin 
$\Leftrightarrow$

sheets of cadmium form excellent shields for the absorption of thermal neutrons. Paraffin, water, or other hydrogen-containing materials, covered by thin cadmium sheets, may be used as shielding for fast neutrons; the hydrogenous substances will bring the fast neutrons down to thermal energies, and these slow neutrons will then be absorbed by the cadmium.

In the cases of sources where high gamma fluxes are present, such as $\mathrm{Ra}-\mathrm{Be}$ or $\mathrm{Sb}-\mathrm{Be}$ sources, adequate gamma-ray shielding must also be provided.

\section{Protection from Internal Sources}

If neutron sources consisting of powdered materials are used, they must be sealed in secondary containers. Zirconium has been widely used for secondaries inasmuch as it produces but slight changes in the neutron flux.

Whenever a neutron source is dropped, or when deterioration of the container is suspected, the container must be leak-tested. A good practice is to check at leastonce everys.xmonths. Consult Radiation Safety for the proper procedures.

\section{E. Reactors and Accelerators}

\section{Reactor CP-5}

Wear wrist badges containing monitoring film whenever your hands are subject to exposure at CP-5. They are issued upon request by Radiation Safety. Neutron-detecting film is included in all badges that are worn by employees regularly assigned to CP -5 .

Conduct experimental work at the pile under conditions which are approved by the Radiation Safety representatives. Pile operators will assist with the installation of equipment, removal of plugs from beam holes, and other special operations which require the use of the reactor.

Beam holes and plugs are not to be altered except with the permission and assistance of the pile operators. Beam plugs must never be pulled out without warning to others in the area and without monitoring by Radiation Safety. If beam holes are to be opened, beam catchers must be available and the area must be roped off. Beam catchers must either be provided by the CP-5 personnel or, if provided by the experimenter, must be approved by the CP-5 operators. 
Samples must never be inserted or removed from the reactor except in the presence of a pile operator and a Radiation Safety representative. This applies to samples from the pneumatic "rabbit holes" as well as to beam holes. Unwarranted procedures can seriously affect the operation of the pile.

Samples removed from the reactor are to be treated as strong beta and gamma emitters, and therefore must be placed in shielded containers. Any apparatus used in experiments with the reactor may become radioactive; therefore, such equipment should be checked by Radiation Safety at the conclusion of the experiment. Any material or equipment proposed for insertion into the reactor (beam holes or thimbles) must be of design and structure approved by the Director of Reactor Operations. This is essential for safety of the personnel and for continued successful operation of the pile. Furthermore, dimensions will have to be checked so that insertion and removal will occur without difficulty.

\section{The Cyclotron}

Film badges and dosimeters are supplied to everyone who obtains access to Building 211. When the machine is in operation, no one is permitted to enter the cyclotron room or vault. Not only do electrical, magnetic, and radiation hazards exist, but when the beam is operated in air, hazardous quantities of ozone and fluorine are formed. Admission to the cyclotron room when the machine is not operating is by escort only.

\section{The van de Graaif \\ Inasmuch as the activity produced by operation of the van} de Graaff in Building D-203 is small, its location has not been declared an active area. Permanent shielding has been installed as a protection against the chief hazard of fast neutrons. Whenever personnel monitoring devices are necessary, they must be obtained from Radiation Safety.

During operation of the van de Graaff the area is roped off. In any event, check with the operators before entering the experimental area.

For any experiment the equipment, scaffolding and shielding must be provided by the requestor. The type of shielding required will be determined by the nature of the experiment and the radiations involved. Upon request, the van de Graaff operators will give technical help. 


\section{7 \\ 4. Reactor CP-4 (Idaho Falls)}

All work with CP-4, whether experimental or routine, must be conducted in conformance with the established Laboratory safety practices.

The reactor crew will assist you in the installation of equipment and in any modifications of the machine, such as removal of plugs, shields, etc. Under no circumstances undertake any modification without securing approval from the shift operator in charge of the reactor. Whenever the reactor is brought up to power, following any changes in plugs or shields, a radiation survey must be made. 
40 
VI. STORAGE AND DISPOSAL OF ACTIVE SAMPLES

It is important that all stored active samples be clearly labelled at all times, giving pertinent and accurate information about the contents, as well as the name of the person who is responsible.

All areas using radioactive materials are furnished with special receptacles for discarded material. Radioactive wastes must be placed in those receptacles immediately. If any material to be discarded is incompatible with the container provided, contact Radiation Safety.

If there are any questions concerning procedures involved in handling experimental wastes, contact either the Waste Frocessing Committee or Radiation Safety: if possible, this should be done prior to the production of such wastes.

\section{A. Dry Active Wastes}

Although the primary responsibility for handling dry active wastes is borne by Reclamation, it is the responsibility of the waste producer to supply full and complete information concerning the waste.

Standard dry active waste containers (stainless steel cans with a treadle to open the top which are marked on top by a radiation hazard symbol) are provided by Reclamation. All contaminated dry wastes or dry wastes suspected of contamination are to be placed in these receptacles. Readings through the sides of the container must never be greater than $50 \mathrm{mr} / \mathrm{hr}$ at the surface. Use shielded containers for wastes having radiation intensities greater than $50 \mathrm{mr} / \mathrm{hr}$. Upon request, Radiation Safety will provide shielded containers and arrange for the disposal of the waste.

Notify Radiation Safety whenever greater than microcurie amounts of alpha-active material are placed in a dry active waste can. This is of the utmost importance because it is impossible for a surveyor to detect alpha activity through the sides of the container.

If there are items of waste, such as ring stands, tripods, pipes, etc. , that are too large to be placed in the dry active waste cans and if it is not feasible to reduce these items to a size that will fit, seek help from Radiation Safety.

\section{B. Liquid Wastes}

Liquid wastes containing activity must not be discarded down drains. Retention tanks are placed in the waste system only to catch mistakes and to nullify accidents. Retain all active solutions for disposal by 


$$
4: 1
$$

the Reclamation Section. Place such solutions in liquid waste containers, provided by the Reclamation Office on request. Keep aqueous wastes separate from organic liquid wastes.

In general, any liquid waste having an external reading greater than $50 \mathrm{mr} / \mathrm{hr}$ at the surface of the container requires a shielded container which may be obtained from the Reclamation Section.

At the time a clean container is delivered, four copies of the Liquid Waste Transfer Form are provided. (See sample copy, p. 43-A.) Use one of these forms to record the nature and quantity of material being placed in the container. Make an entry every time an addition is made to the container. An accurate record will expedite the disposal procedure.

When you wish to have the container removed, sign the handwritten $\log$ and take it to the official representative of your division or department, who will make up three typewritten copies of the form. Check the typed information against the original data. Sign the typed copies and the original; obtain approval signatures from Special Materials and Radiation Safety. Retain one copy and send the original and two typed copies to the Waste Processing Group, Chemical Engineering Division, Building 310. Reclamation will pick up only those containers for which properly authorized forms are prepared.

At the present time there is no routine method for liquid active waste disposal at the Idaho Division Site. Consult your Radiation Safety representative whenever you have a disposal problem.

\section{Ventilated Storage for Gaseous Emitters}

Many solutions of radioactive materials generate gases as a result of decomposition of the solvent by the emitted radiations. If such solutions are kept in closed containers, loosen the seals periodically to permit the escape of these gases and to prevent the building up of pressure sufficient to burst the container.

These solutions should be labelled and kept in approved hoods which are provided with filters and have adequate ventilation. In general, only such amounts of material as are necessary for immediate experiments should be stored in a laboratory. Turn excess amounts over to Special Materials for storage in their specially ventilated vaults.

\section{Use of Secondary Containers in Storage}

When radioactive materials are being stored, good practice requires the use of secondary containers. These are to be of sufficient volume to contain the activity in case of damage or breakage of the 


\section{3}

\section{LIQUID WASTE TRANSFER}

NAME John Doe

SITE \& BUILOING D-399

VOLUME $9950 \mathrm{mi}$
DIVISION Chemistry

ROOM A-198

SOLUTION IS AQUEOUS $\mathrm{x}$ ORGANIC

PAPERS RECEIVED 310

PAPERS RECEIVED 306

RECLAMATION DATE OF TRANSFER DESCRIPTION OF CONTAINER 6 gallon polythene in stainless steel secondary

CONTAINER NUABER 6 LP 2501

\begin{tabular}{|c|c|c|c|c|c|c|c|c|}
\hline \multirow{2}{*}{ DATE } & \multirow{2}{*}{ VOL UME } & ACIDS & ALKALINE & SOLVENT & DTHER CHEMICALS & RADIOACTIVE ALPHA* & RADIOACTIYE BETA. GAMMA* & \multirow{2}{*}{$\begin{array}{l}\text { ADDED BY } \\
\text { (GIVE YOUR } \\
\text { (NITIALS) } \\
\end{array}$} \\
\hline & & conc. & CONC. & CONC. & cone. & CONC. & KINO. CONC. & \\
\hline $6-1-56$ & $100 \mathrm{ml}$ & $\mathrm{HNO}_{3} \quad 1 \mathrm{M}$ & & & & $\begin{array}{r}\text { SPECIYY } \\
10^{2} \mathrm{~g} / 1\end{array}$ & UNITS & JD \\
\hline $6-4-56$ & $2000 \mathrm{ml}$ & $\mathrm{HNO}_{3} 0.1 \%$ & & & & $5 \mathrm{~g} / 1$ & & $\mathrm{JD}$ \\
\hline $6-5-56$ & $250 \mathrm{mi}$ & & & $\mathrm{H}_{2} \mathrm{O}$ & $\mathrm{UO}_{2}\left(\mathrm{NO}_{3}\right) 50 \mathrm{~g} / \mathrm{I}$ & U & & JS \\
\hline $6-5-56$ & $600 \mathrm{ml}$ & & & $\mathrm{H}_{2} \mathrm{O}$ & $\mathrm{UO}_{2}\left(\mathrm{NO}_{3}\right) 30 \mathrm{~g} / 1$ & $\mathrm{U}$ & & JS \\
\hline $6-7-56$ & $6000 \mathrm{ml}$ & $\mathrm{HNO}_{3} \quad \mathrm{IM}$ & & Hexone *: & & $6 \times 10^{8} a$ from & & \\
\hline & & $\mathrm{HCl} \quad 1 \mathrm{M}$ & & Benzene* & & $P u, P o, A m, U$, etd &. & JS \\
\hline & & $\mathrm{H}_{2} \mathrm{SO}_{4} \quad 1 \mathrm{M}$ & & & & & & \\
\hline $6-8-56$ & $1000 \mathrm{ml}$ & $\mathrm{HNO}_{3} \cdot 3 \mathrm{M}$ & & & UNH & Pu $10^{5} \mathrm{c} / \mathrm{m} / \mathrm{ml}$ & mixed $E^{2} P-10^{7} \beta / \mathrm{m}$ & JD \\
\hline & & & & & & & & \\
\hline TOTALS & $9950 \mathrm{ml}$ & & & & & & & \\
\hline
\end{tabular}

REMARKS: PLEASE LIST ANY MATERIAL WHICH wOULD NECESSITATE SPECIAL PRECAuTIONS. Note that there is Pu and Po present * Only a trace of these, just whatever is soluble in water, no more.

SPECIAL MATERIALS APPROVAL J. C. Smith

EXTERNAL SURVEY $<0.05 / 1^{\prime \prime} \mathrm{H}$ and $<1 \mathrm{M}$

RADIATION SAFETY APPROVAL B. G. SamSON

*Identify principel element involved whenever possible.
I CERTIFY THAT THE WASTE SUBMITTED IS IDENTIFIED HEREIN CHEMICALLY AND RADIOCHEMICALLY. ALL SPECIAL PRECAUTIONS NECESSARY ARE INDICATED.

(SIGNED) John Doe

(DATE) June 8,1956

DISPOSITION: 


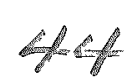

primary vessel, thereby preventing the spread of contamination, as well as reducing the possibility of subjecting personnel to internal radiation. In the case of liquids, a safe procedure is to fill the space between the containers with an inert absorbent.

\section{E. Contaminated Equipment}

Under no circumstances may contaminated equipment be stored in a laboratory or be returned to the stockroom. If the equipment is of such value that it should be re-used, make arrangements for its storage in a safe location in accordance with local building regulations and with the approval of Radiation Safety.

Contaminated equipment which is no longer of any use may be discarded in the dry active waste can. If too large for such disposal, request a survey and disposal information from Radiation Safety.

If the equipment is to be decontaminated and reclaimed, make arrangements with Radiation Safety to initiate the necessary work orders. 
VII. TRANSPORTING ACTIVE MATERIALS ON AND OFF THE SITE

All precautions must be taken so that no person shall be overexposed to radiations from materials which are being transported. All shipments of radioactive or fissionable materials, with the exception of radioactive wastes and/or contaminated materials, are made through the facilities of the Special Materials Department. No transfer of such materials, whether on or off-site, is to be made without the authorization. of this Department. Radioactive wastes and/or contaminated materials are handled by the Reclamation Section of the Plant Operations Division.

If active material is to be shipped, whether from one active area within the Laboratory to another or to destinations outside the Laboratory, contact the Special Materials representative. He will give instructions as to the proper packaging in each instance, make arrangements for the necessary survey by Radiation Safety, and make provisions for the actual transfer.

All assignments of active material are to be from person to person, and not from an individual to a location. It is essential that the receiver have an accurate knowledge of the activities involved and that he know the chemical composition of the material. The outer container should be carefully labelled to provide this information.

In general, all active material must be shielded so as to provide sufficient attenuation of the particular type of radiation involved. The package must be such that there can be no leakage of radioactive material under the conditions normally incident to transportation. Gamma or beta radiation must not exceed $200 \mathrm{mr} / \mathrm{hr}$ at the surface of the package; for neutrons, the maximum permissible radiation is $2 \mathrm{mrep} / \mathrm{hr}$ at one meter. Alpha radiation may be expected to be entirely absorbed within the package. Solutions must always be transported in gasketed, tight, secondary containers, with sufficient chemically inert absorbent material to prevent the escape of any solution should breakage occur. Pyrophoric material must be placed in containers that are non-combustible. 


$$
\text { (x) }
$$


VIII. IRRADIATING SAMPLES

The Laboratory has several facilities for the irradiation of materials. Inasmuch as the radiation problems are peculiar to each installation and inasmuch as each is operated by skilled personnel who are aware of the precautions necessary, no attempt has been made to outline the safety procedures to be followed at the se locations. Instead, the following paragraphs indicate the type of facility available and the proper location to make arrangements for the use of the facility. It is expected that instructions will be provided at the time requests are made.

\section{A. Reactor CP-5}

Any material inserted into CP-5 must have the prior approval of the Director of Reactor Operations (Extension 494). When all necessary information is provided, instructions for packaging and shipping to the reactor will be given. Packaging is done by the requestor. Arrangements for processing the packages in and out of the reactor must be made with the CP-5 operators.

Samples removed from the reactor are strong beta and gamma emitters and therefore axe placed in heavily shielded containers. The requestor must be prepared to handle such heavy equipment upon return of the irradiated material to them.

\section{B. The Cyclotron}

For irradiation of samples in the cyclotron, Building 211 , arrangements must be made with the group leader of cyclotron operations.

In general, packaging of the sample is not necessary: however, the requestor is expected to mount the sample in the target assembly provided by the cyclotron group. During the irradiation the requestor is expected to stand by with the operating personnel.

\section{The van de Graaff}

Arrangements for use of the van de Graaff for experimental work are made through the office of the Physics Division. It will be necessary for the requestor to supply equipment and shielding. Upon request, the van de Graaff operators will give technical help.

D. X-Ray and Gamma-Ray Facilities

Facilities for radiographic examination and for X-ray diffraction are available in the Metallurgy, Chemistry, and Chemical 


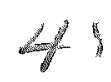

Engineering Divisions. Contact the appropriate divisional office for use of any of these facilities. Special instructions are given at the time that permission for use is granted.

A 300-curie cobalt-60 source is available in Building 202 for irradiating materials with gamma rays. In addition, use can also be made of three 250-KVF X-ray machines, one of which is capable of providing 130,000 roentgens per minute. In general, considerable advance notice is necessary for the use of these facilities. Arrangements for irradiations are made with the Assistant Director of the Biological and Medical Research Division. Operators are available for the conduction of the irradiations; however, all necessary equipment and service for setting up apparatus must be provided by the requestor.

\section{E. Reactor CP-4 (Idaho Falls)}

Samples to be irradiated in CP-4 must be approved by the Division Director. They must be properly constructed and packaged to prevent radioactive contamination of the reactor and surrounding areas. All such samples, following irradiation, must be considered as beta-gamma sources and proper plans for their manipulation must be formulated before samples are placed in the reactor. No samples may be inserted or removed from the reactor unless the shift operator is fully advised concerning the procedures. Samples are to be inserted and/or removed only when the reactor is shut down. Deviations from this procedure must be approved by the Division Director. 


\section{4 \\ IX. DECONTAMINATION PROCEDURES}

A. Personal Decontamination

Extreme personal cleanliness is the first rule in preventing contamination of the skin. Wash all exposed portions of your body at frequent intervals when you are working with radioactive materials. Routinely, wash and monitor your hands before you leave an active area.

Take extreme precautions to avoid abrasions, cuts and puncture wounds. Do not work with radioisotopes if there are cuts or abrasions on any exposed part of your body: report the condition to your supervisor. If a skin break occurs while you are working in an active area, notify your supervisor, have the wound surveyed for contamination by Radiation Safety, and report to the Health Division for treatment.

If your skin is broken by a contaminated object, take immediate action to remove contamination which may possibly have entered the wound. Wash the wounded area under large volumes of running water; spread the edges of a cut to permit flushing action by the water: and stimulate bleeding. (A light tourniquet which stops the venous return without restricting the arterial flow is sometimes helpful.) After the emergency precautions have been taken, report to the Health Division for treatment. The emergency precautions are followed in order to prevent contamination from entering the blood stream during the time interval needed to reach the Health Division.

The best method for general decontamination of the exterior surfaces of the hands and other parts of the body is a thorough washing with soap and water, or with detergent, such as Tide or pHisoderm. If the contamination is localized, it is often practical to mask off the affected area and cleanse with swabs before risking the danger of spreading the contaminant by general washing.

If the exact nature of the contaminant is known, and if a given reagent has been proven to be effective for the removal of such contamination, immerse the hands in that reagent as soon as they become contaminated. Then wash in warm water with a mild soap, and rinse in clean water. Detergents and wetting agents are often effective for decontamination, but they should be used sparingly, as they may lead to the development of skin sensitivity. Never use organic solvents; they may cause the radioactive materials to penetrate the skin.

Use the following procedure to effect personal decontamination. If decontamination cannot be verified by surveys, report to the Health Division immediately. 


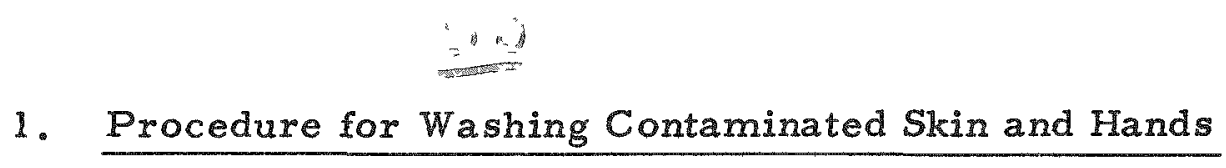

a. Wash thoroughly for two to three minutes by the clock. Use tepid (not hot) water and a mild soap or detergent such as Tide or pHisoderm. Cover the entire surface of the contaminated area with a good lather. Rinse off completely with water. Repeat the process at least three times. Do not use abrasive or highly alkaline soaps or powders.

b. Eight minute surgical scrub. If the above procedure is not enough to remove all dirt and contamination, scrub the hands for a period of at least eight minutes by the clock with a liquid or cake soap, hand brush, and tepid water, being sure to brush the entire surface of the hands, especially around the nails and between the fingers. Light pressure should be exerted on the brush - do not press so hard that the bristles are bent out of shape. Eight minutes is usually a sufficient time to allow three complete changes of tepid water and soap. Each one of the se three washings should be so thorough that the brush will cover all areas a minimum of four strokes. A convenient routine is to start by scrubbing one thumb, being sure to brush all surfaces, proceed to the space between the thumb and first (index) finger and similarly to each finger and the webs between the fingers.

Give attention to the palm and the back of the hand and, finally, scrub the nails and cuticles before proceeding in an exact manner with the other hand.

c. Use the hand counter to verify the removal of contamination, then use lanolin cream to soften the hands and prevent chapping.

d. Discard the hand brush and towels after they have been used for the removal of contaminated material (use an active waste can).

\section{Titanium Dioxide to Remove Fission Products}

Titanium dioxide may be used as a paste or slurry made by shaking the powder into the wet palm of the hand until a good paste is formed. Run tap water over the hands continually so that the paste is kept wet, and apply this lather thoroughly to all hand surfaces, especially around the finger nails, for a minimum time of two minutes.

Rinse off thoroughly with luke-warm water and follow by a thorough washing with soap and water and a hand brush. If any of the paste is left under the nails after washing, it will form a rather hard cake which is difficult to remove. 


\section{- \\ 3. Potassium Permanganate to Remove Plutonium}

a. Mix an equal volume of a saturated solution of potassium permanganate with $1 \%$ sulfuric acid solution $(0.2 \mathrm{~N})$. Pour this weak acid solution over the wet hands, covering the nails and cuticles thoroughly. Rub the entire surface lightly with a hand brush without applying enough pressure to bend the bristles out of shape.

Use running water (tepid, not hot), and rinse off after the application has thoroughly covered the hands. Do not continue this procedure for more than two minutes. This process will stain the skin a deep brown.

b. Use a freshly prepared $5 \%$ sodium acid sulfite solution in the same manner as above, using the hand brush and tepid running water for a two-minute period. This solution will remove the brown stain on the skin. (It is convenient to keep labelled packages containing $10 \mathrm{gm}$ $\mathrm{NaHSO}_{3}$ on hand and dissolve this amount in $200 \mathrm{ml}$ of water.)

The complete procedure above may be repeated several times without appreciable harm to the skin if each washing is limited to two minutes.

An abundance of water is essential. To wash other skin surfaces such as neck, face, ears, etc., the solutions may be applied with absorbent cotton. If another person is manipulating the solution, rubber gloves should be worn as protection from both contamination and permanganate staining.

Protective clothing which has become contaminated must be left in the work area or other designated locations until it is decontaminated or discarded or until the activity has decayed to a safe level. Wrap the clothing in heavy paper or vinyl sheeting to prevent airborne contamination.

\section{B. Decontaminating Laboratory Equipment and Apparatus}

All items which have been used with radioactive materials are to be considered as contaminated unless proved otherwise. Such apparatus must be isolated in the working area. Have Radiation Safety affix a radiation hazard label, sticker, or stencil to the contaminated material until cleaning can be performed. If it is necessary to dismantle any equipment prior to decontamination procedures, a careful survey must be made during the operation. 


$$
5,2
$$

If decontamination of equipment is desired, the initial attempts are to be made by the scientist. Treatment will depend upon the nature of the contaminant and upon the surface which is contaminated. If the initial decontamination efforts are unsuccessful, the facilities of the Reclamation Service are to be requested by application through Radiation Safety representatives.

Wash all glassware with chromic acid cleaning solution or with concentrated nitric acid as a routine procedure following use. If these leave the glassware still contaminated, mineral acids or solutions of ammonium citrate, trisodium phosphate, or ammonium bifluoride may be tried. If decontamination is difficult, it is usually more convenient to replace the items. In order to prevent accidental return to stock or to other use, break discarded glass equipment before disposal.

All metal tools are to be surveyed after use to detect possible contamination. Metal objects may sometimes be decontaminated with dilute mineral acids, a $10 \%$ solution of sodium citrate, or ammonium bifluoride: the use of strong acids on metal tools may corrode them, thereby causing greater difficulty in future decontamination procedures. If other procedures fail, hydrochloric acid may be used on stainless steel. Since this will remove some of the surface, use it only as a last resort, unless the equipment is to be discarded as decontaminated scrap. Brass polish is an excellent decontaminant for brass. Oxalic acid generally is satisfactory for rusty surfaces. Titanium dioxide paste is a good agent for removing fission products from metallic surfaces; do not let the paste harden, for it is then extremely difficult to remove.

Plastics may be decontaminated with ammonium citrate, dilute acids, or organic solvents.

Survey laboratory equipment for residual contamination following decontamination procedures. If the level of activity is still greater than that specified as permissible, contact Reclamation Services through Radiation Safety for additional decontamination.

Equipment which may have come in contact with radioactivity must not be sent away from the Laboratory for repair unless it has been checked and approved by the Radiation Safety Section.

$$
\text { C. Decontaminating Laboratory Work Areas }
$$

Clean floors and benches with wet or oil mops; never with a dry mop, since this may create a dust hazard.

Methods for decontaminating metal, glass and plastic surfaces are described in the previous section. 


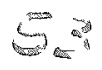

For linoleum decontamination use kerosene, ammonium citrate solution, or dilute mineral acids: take care not to dissolve sealing compounds at the edges and between the cracks in the linoleum.

Ceramic tile may be decontaminated by the use of mineral acids, ammonium citrate, or trisodium phosphate.

Paint is sometimes decontaminated successfully by using a solvent such as acetone, trichloroethylene, Stoddard's solvent, or by a $10 \%$ hydrochloric acid solution: however, this procedure may dissolve some of the paint. It is preferable to remove the paint and apply new coatings.

To decontaminate concrete, try scrubbing with water and a detergent such as Tide. Although hydrochloric acid has been used successfully on concrete, it is not recommended as it generally increases the porosity and further embeds the activity.

If the detergent treatment is not successful, the surface concrete may have to be removed with a chisel. Similarly, contaminated wood surfaces may have to be planed.

The above information refers to fixed contamination. If a dry spill occurs on any surface, use vacuum equipment with a high efficiency filter as the first step in the decontamination process. Contact Radiation Safety to obtain this equipment.

Contamination from heavy metal activities may be removed by using a reagent such as Versene (adjusted to a $\mathrm{pH}$ between 8 and 10 by the use of sodium hydroxide or sodium carbonate), or by a combination of products such as Versene and Tide.

It should be noted that a number of the materials recommended as solvents or cleaners are toxic and may cause burns if splashed on the body. It is important to use the proper concentration and adequate ventilation during all decontamination operations. 
54 
X. BIBLIOGRAPHY

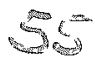

In addition to the references given in Section IV $-G$, the following may also be used:

Radiation Safety

Journals and Periodicals

1. Warren, S., Waste Disposal Symposium, Nucleonics 4 , No. 3, pp 9-23(1950)

2. Evans, T. C., Fast Neutron Hazard, Nucleonics 4, No. 3, pp 2-8 (1950)

3. Morgan, K. Z., Shipping of Radioisotopes, J. App. Phys. 19, p 593 (1948)

Handbooks

1. Radiological Health Training Section, Sanitary Engineering Center, Radiologıcal Health Handbook, Cincinnati, Ohio (October 1955)

2. National Bureau of Standards Handbook 48, Control and Removal of Radioactive Contammation in Laboratories, (December 15, 1951)

3. National Bureau of Standards Handbook 42, Safe Handling of Radioisotopes, (September 1949)

Textbooks

1. Plle Neutron Research, D. J. Hughes, Addison-Wesley, Cambridge, Massachusetts, 1953

2. Radioisotopes: Industrial Applications, C. H. Guest, Pitman Publishing Corp., New York, N.Y., 1951

3. Industrial and Safety Problems of Nuclear Technology, M. H. Shamos and S. G. Roth (Eds.), Harper and Bros., New York, N. Y., 1950

4. Sourcebook of Atomic Energy, S. Glasstone, D. van Nostrand, New York, N. Y., 1950

5. Introduction to Radiochemistry, G. Friedlander and J. W. Kennedy, J. Wiley and Sons, New York, N.Y., 1949

Industrial Hygiene

Bulletins, Periodicals and Technical Papers

1. AMA Archives of Industrial Health, formerly the AMA Archives of Industrial Hygiene and Occupational Medicine, American Medical Association, Chicago, Illinois 


\section{6}

2. American Industrial Hygiene Association Quarterly, American Industrial Hygiene Association, Chicago, Illinois

3. Division of Industrial Hygiene, U. S. Public Health Service

4. Division of Labor Standards, U. S. Department of Labor, Washington, D. C.

5. Industrial Hygiene Digest, Industrial Hygiene Foundation, Mellon Institute, P.ttsburgh, Pennsylvania

6. Industrial Medicine, American Medical Association, Chicago Illinois

7. Public Health Reports, U. S. Department of Health, Education and Welfare, Public Health Service

8. U. S. Bureau of Mines Export Station, Pittsburgh, Pennsylvania

Textbooks

1. Industrial Dust, P. Drinker and T. F. Hatch, Mc Graw-Hill Book Company, 330 West 42 nd Street, New York, N.Y., Second edition, 1954

2. Exhaust Hoods, J. M. Dalla Valle, The Industrial Press, New York, N. Y., Second Edition, 1952

3. Handbook of Dangerous Materials, W. J. Sax, Reinhold Publishing Corp., New York, N. Y., 1951

4. Industrial Ventilation, A Manual of Recommended Practice, American Conference of Government Industrial Hyguene, Edward Bros, Inc., Amn Arbor, Michigan, 1951

5. Chemistry of Industrial Toxicology, H. B. Elkins, John Wiley \& Sons, New York, N. Y., 1950

6. Colorimetric Determination of Traces of Metals, E. B. Sandell, Interscience Publishers, Inc., New York, N. Y., Second Edition, 1950

7. The Analytical Chemistry of Industrial Poisons, Hazards and Solvents, M. B. Jacobs, Interscience Publishers, Inc., New York, N. Y., Second Edition, 1949

8. Industrial Toxicology, L. T. Fairholl, The Williams \& Willins Compaizy, Baltimore, 1949

9. Industrial Toxicology, A. Hamilton and H. L. Hardy, Paul Hoeber, New York, 1949

10. Industrial Hygıene and Toxicology, Frank A. Patty (and others), Interscience Publishers, Inc., New York, N. Y., Volume I - 1948, Volume II - 1949.

11. Design of Industrial Exhaust Systems, J. L. Alden, Industrial Press, New York, N. Y., 1948

12. Micrometrics, J. M. Dalla Valle, Pitman Publishing Corp., New York, N. Y., Second Edition 1948 
5

13. Occupational Medicine and Industrial Hygiene, R. T. Johnstone, W. B. Saunders Company, Philadelphia, Penn., 1942

14. Industrial Health Engineering, A. Brandt, John Wiley \& Sons, Inc., New York, N. Y., 1947

15. A Textbook of Occupational Diseases of the Skin, L. Schwartz and L. Tulipan, Lea and Febiger, Philadelphia, Pennsylvania, 1947.

16. Noxious Gases and the Principles of Respiration Influencing Their Action, Y. Henderson and H. W. Haggard, Reinhold Publishing Corp., New York, N. Y., 1943

17. Toxikologie und Hygiene der Technischen Losungsmittel, K. B. Lehmann and F. Flury, Julius Springer, Berlin. English translation, Williams and Wilkins, Baltimore, 1943

18. Occupational Diseases - Diagnosis, Medicolegal Aspects and Treatment, R. T. Johnston, W. B. Saunders Company, Philadelphia, Pennsylvania, 1942

19. Toxicity of Industrial Organic Solvents, E. Browning, Report \#80, Industrial Health Research Board, London (1st American Edition, Chemical Publishing Company, New York, N. Y., 1938)

20. Respirations, J. S. Haldane and J. G. Priestly, Yale University Press. New Haven, Connecticut, 1935 
$5 x$ 


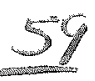

\section{APPENDIX I}

Technique for Putting on and Removing Rubber Gloves

Use surgical rubber gloves during procedures where hand contamination is a possibility. Prepare the gloves in advance by powdering the insides with talc; then fold the wrist portions of the gloves to form a cuff of about two inches.

To put on the gloves, the following procedure is recommended:

1. Powder the hands well with talc.

2. Without touching the exterior of the glove, grasp it at the folded cuff. Then pull on to the fingers and hand, still leaving the cuff in the folded position.

3. Lift the second glove by inserting the fingers of the gloved hand beneath the cuff; then pull this glove onto the bare fingers and hand.

4. Turn the cuffs of both gloves back over the wrists, being extremely careful not to touch the bare skin.

5. Finally, work any loose-fitting glove fingers into position in the same manner as you would for cloth gloves.

Removal of the gloves is accomplished in the reverse order. Let the fingers of one gloved hand grasp the beaded rim of the top of the glove on the other hand without touching the skin or the inside of the glove. Using traction, pull the glove from the hand by inverting the glove. The index finger of the bared hand is now inserted beneath the beaded rim of the top of the other glove. Again, pull the glove from the hand by inverting the glove. Avoid contacting the exterior surface of the glove. 
60

60
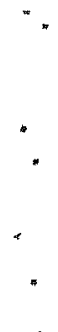

$-$

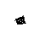

$-$

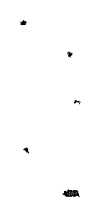

-

-

.

$\therefore$ 


\section{APPENDIX II}

\section{General Safety Precautions}

Because of the additional complication due to the presence of radioactive materials in many laboratory operations, it is especially important to observe all the rules pertaining to safe practice in those operations. An incident which might pass as a "near miss" in an ordinary laboratory might well result in more serious consequences where radioactive materials are involved. The following information is presented in order to give an idea of some of the more important rules and good practices which should be followed in laboratory operations, although it is by no means all-inclusive nor detailed.

There are five specific hazards associated with most laboratories: glass cuts, chemical burns, electric shock, toxicity, and fire. Of these five hazards, chemical burns have probably accounted for the majority of the severe injuries, and cuts from glassware have generally accounted for the most frequent injuries. Here are some of the ways in which you may prevent injuries due to these hazards.

Glassware

Use care in the selection and use of glass equipment in order to prevent breakage and subsequent injury from broken glass and the contents of the apparatus. Remember to guard against the three major causes of glass breakage: mechanical impact, thermal shock, and pressure differential. Always handle broken glass with extreme care; collect it with a broom or brush and dustpan, and place it in the special containers available for its disposal. Frequently inspect battery jars and large beakers for cracks. When handling large glass items, use leather gloves which will help prevent slipping and will protect your hands should the glass break.

\section{Chemical Burns}

Chemical burns can best be prevented by combining good laboratory technique with the wearing of adequate personal protective equipment. For most routine laboratory operations properly fitted safety glasses are adequate: however, when you are performing work which is potentially dangerous, wear a complete face shield. Laboratory coats, aprons, overalls, smocks and other similar garments that are specially impregnated or treated to be fire resistant, or resistant to chemical splash, are available and should be worn when the nature of the work dictates. Gloves of rubber, canvas, leather, etc., are also obtainable, and should be worn as the situation warrants. 
Electric Shock

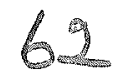

Electrical hazards exist in all laboratories. Control of this hazard is of importance because electrical accidents are more likely to be fatal than any other type. The severity of an electrical shock depends upon: 1. Body resistance: 2. Voltage and frequency: 3. Amount and nature of current: 4. Current path through body: 5. Length of time current passes through body: and 6. Element of anticipation. To reduce accidents due to this cause concentrate your efforts in three areas: design, installation, and operation of electrical equipment. The National Electric Code (National Board of Fire Underwriters Pamphlet No. 70, National Board of Fire Underwriters, 85 John Street, New York 38, New York) gives minimum requirements in all three areas. When apparatus is designed for maximum safety and is installed and operated with due regard for prevention of shock and and fire, freedom from accidents usually follows.

Toxicity

There are three types of industrial exposure to chemicals: contact with the skin and eyes, inhalation, and ingestion. The most common result of excessive contact of chemicals with the skin is a localized irritation or burn, although some materials are absorbed through the skin rapidly enough to produce systemic poisoning. By using proper personal protective equipment such as face shields, laboratory coats, gloves, and correct respiratory equipment, you will be protected against most types of exposure.

Fire

Become familiar with the types of fire hazards which are present in your laboratory. Learn how fires may possibly get started; then take all reasonable precautions to prevent them. Fire prevention in the Laboratory begins with the isolation of hazardous operations and proper planning of extinguishing procedures in the event a fire does start. Have the proper extinguishing equipment near at hand and learn how to use it.

\section{Safety Committees}

All of the scientific and technical divisions of the Laboratory have safety committees. For information concerning safety and fire protection, contact the safety committee of your group. If the committee is not able to resolve a problem, or if the committee wishes more information relative to safety, contact Industrial Hygiene or Radiation Safety of the Industrial Hygiene and Safety Division. 


\section{2}

Selected Bibliography - Laboratory Safety

Following is a list of publications available from Industrial Hygiene and Safety which pertain especially to safety problems that may arise during the course of operations of a laboratory.

Chemicals

1. Manufacturing Chemists Association, Inc., Chemical Data Sheets. These data sheets contain properties and essential information for the safe handling and use of specific chemicals.

2. National Safety Council, Industrial Data Sheets, Chemical Series. These are data sheets similar to (1) above.

3. Manufacturing Chemists Association, Inc., Guide for Safety in the Chemical Laboratory, D. Van Nostrand Company, New York, New York, 1954.

4. Bureau of Fire Prevention, City of Los Angeles Fire Department, Dangerous Chemicals Code, Parker and Company, Los Angeles, California, 1951.

\section{Compressed Gases}

Compressed Gas Association, Inc., Safe Handling of Compressed

Gases, Pamphlet P-1, New York, New York, 1951.

Fire Prevention

National Fire Codes, National Fire Protection Association

Volume I - Flammable Liquids, Gases, Chemicals and Explosives

Volume II - Dust Explosions

Volume IV - Extinguishing and Alarm Equipment

Volume V - National Electric Code

\section{Alkali Metals}

1. Liquid Metals Handbook, Atomic Energy Commission, Department of the Navy, (NAVEXOS P-733), Washington, D.C., 1954

2. Safe Handling of Alkali Metals, H. E. Webb, Jr., and others, Argonne National Laboratory, Lemont, Illinois, 1953. 
64

Pressure Vessels

1. Rules for Construction of Unfired Pressure Vessels, American Society of Mechanical Engineers, 29 West 39th Street, New York, New York, 1952

Industrial Safety

1. Accident Prevention Manual for Industrial Operations, National Safety Council, 425 North Michigan Avenue, Chicago, Illinois, 1955

2. Industrial Safety, R. P. Blake, Prentice Hall, Inc., New York, New York, 1953 


\section{APPENDIX III}

\section{SURVEYING AND MONITORING INSTRUMENTS}

\begin{tabular}{|c|c|c|c|c|c|c|}
\hline Name & $\begin{array}{c}\text { Type of } \\
\text { Instrument }\end{array}$ & $\begin{array}{l}\text { Power } \\
\text { Supply }\end{array}$ & $\begin{array}{c}\text { Type of } \\
\text { Radiation } \\
\text { Detected }\end{array}$ & $\begin{array}{c}\text { Method of } \\
\text { Discriminating }\end{array}$ & Useable Range & Purpose \\
\hline Zeus & $\begin{array}{l}\text { Ionization } \\
\text { Chamber }\end{array}$ & Battery & $\alpha \beta \gamma$ & $\begin{array}{l}2 \text { Sliding } \\
\text { Absorbers }\end{array}$ & $\begin{array}{l}5 \mathrm{mr} \text { to } 2.5 \mathrm{r} / \mathrm{hr} \\
5 \mathrm{M} \text { to } 20,000 \mathrm{M}\end{array}$ & $\begin{array}{l}\text { Portable } \\
\text { Survey Meter }\end{array}$ \\
\hline Juno & $\begin{array}{l}\text { Ionization } \\
\text { Chamber }\end{array}$ & Battery & $\alpha \beta y$ & $\begin{array}{l}2 \text { Sliding } \\
\text { Absorbers }\end{array}$ & $\begin{array}{l}5 \mathrm{mr} \text { to } 2.5 \mathrm{r} / \mathrm{hr} \\
5 \mathrm{M} \text { to } 20.000 \mathrm{M}\end{array}$ & $\begin{array}{l}\text { Portable } \\
\text { Survey Meter }\end{array}$ \\
\hline Juno & $\begin{array}{l}\text { Ionization } \\
\text { Chamber }\end{array}$ & Battery & $\alpha \beta \gamma$ & $\begin{array}{l}2 \text { Sliding } \\
\text { Absorbers }\end{array}$ & $25 \mathrm{mr}$ to $25 \mathrm{r} / \mathrm{hr}$ & $\begin{array}{l}\text { Portable } \\
\text { Survey Meter }\end{array}$ \\
\hline Sampson & $\begin{array}{l}\text { Tonization } \\
\text { Chamber }\end{array}$ & Battery & $a \not b y$ & None & $\begin{array}{l}0-25 \mathrm{M} \\
0-35 \mathrm{mr} / \mathrm{hr}\end{array}$ & $\begin{array}{l}\text { Portable } \\
\text { Survey Meter }\end{array}$ \\
\hline C P Meter & $\begin{array}{l}\text { Ionization } \\
\text { Chamber }\end{array}$ & Battery & $a \beta s$ & $\begin{array}{l}1 \text { Sliding } \\
\text { Absorber }\end{array}$ & $5 \mathrm{mr} / \mathrm{hr}$ to $2.5 \mathrm{r} / \mathrm{hr}$ & $\begin{array}{l}\text { Portable } \\
\text { Survey Meter }\end{array}$ \\
\hline Electroscope & $\begin{array}{l}\text { Ionization } \\
\text { Chamber }\end{array}$ & Battery & $\alpha \not \beta \gamma$ & 1 Absorber & $1 \mathrm{mr} / \mathrm{hr}$ to $200 \mathrm{mr} / \mathrm{hr}$ & $\begin{array}{l}\text { Portable } \\
\text { Survey Meter }\end{array}$ \\
\hline $\begin{array}{l}\text { Pocket } \\
\text { Dosimeter }\end{array}$ & $\begin{array}{l}\text { Ionization } \\
\text { Chamber }\end{array}$ & $\begin{array}{c}\text { External } \\
\text { Source }\end{array}$ & $\gamma_{\mathrm{n}}$ & None & $1 \mathrm{mr}$ to $10 \mathrm{r}$ & $\begin{array}{l}\text { Personnel } \\
\text { Monitoring }\end{array}$ \\
\hline Fi $1 \mathrm{~m}$ Badge & $\begin{array}{l}2 x-\operatorname{Ray} \\
\text { fi } 1 \mathrm{~m}\end{array}$ & - & poy & $\begin{array}{l}\text { Cd Shield } \\
\text { Partial }\end{array}$ & $\begin{array}{l}20 \mathrm{mr} \text { to } 3 \mathrm{r} \\
3 \mathrm{rto} 30 \mathrm{r}\end{array}$ & $\begin{array}{l}\text { Personne } 1 \\
\text { Monitoring }\end{array}$ \\
\hline $\begin{array}{l}\text { Thimble } \\
\text { Chamber }\end{array}$ & $\begin{array}{l}\text { Ionization } \\
\text { Chamber }\end{array}$ & External & by & 1 Absorber & $25 \mathrm{mr}$ to $500 \mathrm{r}$ & $\begin{array}{l}\text { Portable } \\
\text { Survey Meter }\end{array}$ \\
\hline $\begin{array}{l}\text { Portable } \\
\text { py Counter }\end{array}$ & $\begin{array}{l}\text { Geiger } \\
\text { Counter }\end{array}$ & Battery & by & 1 Absorber & 0.03 to $20 \mathrm{mr} / \mathrm{hr}$ & $\begin{array}{c}\text { Portable } \\
\text { Survey }\end{array}$ \\
\hline
\end{tabular}




\section{APPENDIX III (CONT'D.)}

\begin{tabular}{|c|c|c|c|c|c|c|}
\hline Name & $\begin{array}{c}\text { Type of } \\
\text { Instrument }\end{array}$ & $\begin{array}{l}\text { Power } \\
\text { Supply }\end{array}$ & $\begin{array}{l}\text { Type of } \\
\text { Radiation } \\
\text { Detected }\end{array}$ & $\begin{array}{c}\text { Method of } \\
\text { Discriminating }\end{array}$ & Useable Range & Purpose \\
\hline $\begin{array}{l}\text { Portable } \\
\text { a Counter }\end{array}$ & $\begin{array}{l}\text { Proportiona } 1 \\
\text { Counter }\end{array}$ & Battery & $a$ & None & $0.2 \mathrm{M}$ to $45 \mathrm{M}$ & $\begin{array}{l}\text { Portable } \\
\text { Survey }\end{array}$ \\
\hline $\begin{array}{l}\text { Tand } \\
\text { Counter }\end{array}$ & $\begin{array}{l}\text { Geiger } \\
\text { Counter }\end{array}$ & $A C$ & $\beta y$ & None & $\begin{array}{l}50 \mathrm{c} / \mathrm{m} \text { to } \\
10.000 \mathrm{c} / \mathrm{m}\end{array}$ & $\begin{array}{l}\text { Personne } \\
\text { Monitoring }\end{array}$ \\
\hline $\begin{array}{l}\text { Foot } \\
\text { Counter }\end{array}$ & $\begin{array}{l}\text { Geiger } \\
\text { Counter }\end{array}$ & $\mathrm{AC}$ & $\beta \gamma$ & None & $\begin{array}{l}500 \mathrm{c} / \mathrm{m} \mathrm{to} \\
100,000 \mathrm{c} / \mathrm{m}\end{array}$ & $\begin{array}{l}\text { Personne } 1 \\
\text { Monitoring }\end{array}$ \\
\hline $\begin{array}{l}\text { Laundry } \\
\text { Counter }\end{array}$ & $\begin{array}{l}\text { Geiger } \\
\text { Counter }\end{array}$ & $A C$ & $\beta \gamma$ & None & $\begin{array}{ll}50 \mathrm{c} / \mathrm{m} & \text { to } \\
10,000 \mathrm{c} / \mathrm{m}\end{array}$ & $\begin{array}{l}\text { Laundry } \\
\text { Checking }\end{array}$ \\
\hline $\begin{array}{l}\text { Hand } \\
\text { Counter }\end{array}$ & $\begin{array}{l}\text { Proportional } \\
\text { Counter }\end{array}$ & $\mathrm{AC}$ & $a$ & None & $\begin{array}{l}20 \mathrm{c} / \mathrm{m} \text { to } \\
10,000 \mathrm{c} / \mathrm{m}\end{array}$ & $\begin{array}{l}\text { Personnel } \\
\text { Monitoring }\end{array}$ \\
\hline $\begin{array}{l}\text { Filter Paper } \\
\text { Counter }\end{array}$ & $\begin{array}{l}\text { Proportiona } 1 \\
\text { Counter }\end{array}$ & $\mathrm{AC}$ & $a$ & None & 0 to $25,000 \mathrm{c} / \mathrm{m}$ & $\begin{array}{l}\text { Analytical } \\
\text { Lab. Work }\end{array}$ \\
\hline $\begin{array}{l}P C 1 \\
\text { Counter }\end{array}$ & $\begin{array}{l}\text { Proportional } \\
\text { Counter }\end{array}$ & $A C$ & $\alpha \beta \gamma$ & $\begin{array}{l}\text { Change Chamber } \\
\text { Voltage }\end{array}$ & 0 to $500,000 \mathrm{c} / \mathrm{m}$ & $\begin{array}{l}\text { Analytical Lab. } \\
\text { Work Background } \\
(5 \mathrm{c} / \mathrm{hr}, 35 \mathrm{c} / \mathrm{m})\end{array}$ \\
\hline $\begin{array}{l}\text { Neutron } \\
\text { Counter }\end{array}$ & $\begin{array}{l}\text { Proportional } \\
\text { Counter }\end{array}$ & $\mathrm{AC}$ & $\begin{array}{c}\text { S10w \&ast } \\
\text { Neutrons }\end{array}$ & $\begin{array}{l}\text { Cadmium and } \\
\text { Parafin } \\
\text { Moderator }\end{array}$ & $\begin{array}{l}\text { Iux of } 0.10,000 \\
n / \mathrm{sec} / \mathrm{cm}^{2}\end{array}$ & $\begin{array}{l}\text { Survey and } \\
\text { Monitoring }\end{array}$ \\
\hline $\begin{array}{l}\text { Radioactive } \\
\text { Gas Detector }\end{array}$ & $\begin{array}{l}\text { Geiger } \\
\text { Counter }\end{array}$ & $A C$ & $\beta \gamma$ & None & $0.10,000 \mathrm{c} / \mathrm{m}$ & $\begin{array}{l}\text { Ar Sampling } \\
\text { for Radioactive } \\
\text { Gases }\end{array}$ \\
\hline
\end{tabular}

An "M" unit equals $1,000 \mathrm{dis} / \mathrm{min} / 100 \mathrm{~cm}^{2}$.

Junos are not normally calibrated for a measurements. 


\title{
APPENDIX IV
}

\author{
Personnel Monitoring Devices
}

Film Badges

The film badge provides a relatively accurate means of determining dosages from beta, gamma, $X$ radiation, and, in special cases, neutron radiation. The films are developed and evaluated by interpreting the blackening of the film in terms of standards which have been exposed to known radiation dosages. The film badge worn by ANL personnel contains special dosimeter films which are capable of measuring dosages from 50 milliroentgens to 500 roentgens. A part of the film packet is covered by a one-millimeter cadmium filter; this portion measures accurately gamma and high energy $\mathrm{X}$-ray dosages. The remainder of the film, all of which is enclosed in a $28 \mathrm{mg} / \mathrm{cm}^{2}$ wrapper, receives all radiation directlythrough an unshielded section of the holder and responds to beta as well as very low energy gamma radiation. For those areas or buildings where there is a possibility of a neutron hazard, a special nuclear track film is enclosed in the film badge. Specialized types of film badges, including wrist badges, head badges, or special body badges, can be readily obtained from the Radiation Safety site office upon request.

Dosimeters

The self-reading pocket dosimeter is a device intended to provide scientists and technicians handling radioactive materials with a quick and reasonably accurate indication of the amount of radiation they have been exposed to during a given period of time. The dosimeter in common use at ANL was designed and fabricated by the former Instrument Research and Development Division and consists of an electroscope with a tiny microscope trained on the electroscope fiber. The dosimeter has a full scale of 100 milliroentgens, but additional scale divisions corresponding to 25 milliroentgens are provided at both ends of the scale. Two other dosimeters, the Cambridge $200 \mathrm{mr}$ and the Cambridge $10 \mathrm{x}$, are employed to a limited extent at the Laboratory. These dosimeters have a full scale of 200 milliroentgens and 10 roentgens respectively. It should be realized that dosimeters, unlike film badges, are insensitive to beta and very low energy gamma radiation. 